\title{
THINKING PAST RIGHTS: TOWARDS FEMINIST THEORIES OF REPARATIONS
}

\section{Genevieve Renard Painter}

The notion of reparations encompasses debates about the relationship between individual and society, the nature of political community, the meaning of justice, and the impact of rights on social change. In international law, the dominant approach to reparations is based on individual rights. This normative framework is out of step with the understanding of reparations circulating among many women activists. I develop a theoretical approach to justice and reparations that helps to explain the gap between the international normative framework and activist discourses. Based on distributive, communitarian, and critical theories of justice, I argue that reparations can be thought of as rights, symbols, or processes. Understanding reparations as either rights or symbols is rife with problems when approached from an activist and feminist theoretical standpoint. As decisions about reparations programs are and should be determined by the political, social, economic, and cultural context, a blueprint for 'a feminist reparations program' is impractical and ill-advised. However, the strongest feminist approach to reparations would depart from an understanding of reparations as a process.

La notion de réparations tient compte des relations entre l'individu et la société, de la nature du politique, de la signification de la justice et de l'incidence des droits dans le changement social. En droit international, l'idée dominante à cet égard est fondée sur les droits individuels. Ce cadre normatif est en décalage avec l'idée que de nombreuses militantes se font des réparations. J'ai élaboré une façon théorique de voir la justice et les réparations qui aide à expliquer l'écart entre le cadre normatif international et le discours militant. Selon cette approche fondée sur des théories distributives, communautaires et critiques de la justice, j'affirme que les réparations peuvent être vues comme des droits, des symboles ou des processus.

$\mathrm{PhD}$. Student, University of California-Berkeley, Jurisprudence \& Social Policy. I am grateful to the members of the Coalition on Women's Human Rights in Conflict Situations. I also thank Kathryn Abrams, Rashida Manjoo, Colleen Sheppard, Anne Saris, Gisèle Eva Côté, Isabelle Solon Helal, Ariane Brunet, Binaifer Nowrojee, Nicola Painter, and Andrew Deak. This paper was awarded the 2011 Audre Rapoport Prize for Scholarship on Gender and Human Rights and the 2011 International Studies Association's prizes from the Human Rights Section and the Feminist Theory and Gender Studies Section. 
D'un point de vue théorique militant ou féministe, le fait de considérer les réparations comme des droits ou des symboles s'accompagne de nombreux problèmes. Étant donné que les décisions au sujet des programmes de réparations sont et doivent être déterminés en fonction du contexte politique, social, économique et culturel, la conception d'un programme de réparations féministe est peu pratique et mal avisée. Toutefois, la meilleure approche féministe face aux réparations $s$ 'écarterait de la vision selon laquelle celles-ci constituent un processus.

\section{INTRODUCTION \& OVERVIEW}

In the aftermath of conflict, a range of strategies emerge to cope with its political, social, economic, and cultural consequences. Women have frequently been at the forefront of demands for justice and reconciliation following periods of conflict. From activist and academic quarters, feminist critiques of the post-conflict justice agenda have emerged. This paper offers a feminist critique of reparations ${ }^{1}$ for massive human rights crimes in times of conflict.

Grave human rights crimes in violent conflict are contexts that have been framed by governments and activists as transitional justice sites. Reparations is a concept that is relevant in other contexts, including reparations between states under the rules of state responsibility, reparations through court processes such as suits brought under the US Alien Tort Claims Act, and reparations for historical injustices, like slavery and colonialism. Their exclusion from this paper is not meant to suggest that a gender analysis of these areas is unnecessary. The focus on transitional justice derives from the observation that this context brings with it an institutional structure (UN, states, NGOs), norms (human rights, international law, development), and communities (diplomats, consultants, NGO activists).

A feminist analysis starts from the position that sex and gender matter and that they interact with other important axes of differentiation, like race, ethnicity, class, and age. From this awareness, a common characteristic of feminist analysis is the effort to reveal features of an issue which other methods overlook. ${ }^{2}$ This includes identifying the gender implications of rules and practices which otherwise appear to be neutral and observing real-life dilemmas from the perspective of the excluded.

According to one framework, a feminist approach to post-conflict prioritizes socio-economic issues, challenges the capitalist development which unfolds in the transitional context, demands the inclusion of non-elite actors in political processes, and draws attention to the way in which "violence against women often alters in form, rather than prevalence, post-transition." Drawing on this framework, the feminist approach that I take in this paper acknowledges that there is no universal, final, or objective truth. The act of feminist theorizing must possess an explicit awareness of the partiality of knowledge and the need to

I refer to reparations, as a concept, in the singular.

Katharine T Bartlett, "Feminist Legal Methods" (1990) 103 Harv L Rev 829.

Christine Bell \& Catherine O’Rourke, "Does Feminism Need a Theory of Transitional Justice?

An Introductory Essay" (2007) 1 International Journal of Transitional Justice 23 at 42-43. 
recognize one's standpoint and travel from it. ${ }^{4}$ As Lacey argues, there is never one feminist analysis of a social problem, rather "it is the beginning of an analytic journey." Post-modern and Third World feminists have argued that the imposition of one theory may deny the particularity of people's experiences and privilege the voices of the dominant over the marginal. ${ }^{6}$ In light of these feminist theories and the contextually-bound nature of any transitional justice moment, this paper offers an improved, rather than a true, understanding of reparations, women, and conflict.

The paper begins by providing an overview of the issues that emerge when studying conflict from a gender perspective. It then explores the meaning of reparations in international law, human rights law, international criminal law, and UN principles, demonstrating that the dominant approach to reparations is based on individual rights. The next section analyzes the understanding of reparations among activists concerned with women and gender equality. This analysis shows that activists have a very broad understanding of reparations which goes far beyond the dominant rights-based approach to reparations. With the aim of understanding the gap between the international normative framework and activist discourses, the next sections of the paper offer theoretical approaches to justice and reparations. A working framework for defining and analyzing reparations is proposed. It argues that reparations programs incorporate a vision of justice, including conceptions of the self, the role of the law, and the remedies to injustice. By asking why reparations programs are established, it is possible to establish a typology of the nature of reparations, as rights, symbols, or processes. The last section offers a feminist theoretical approach to reparations. I analyze the feminist problems raised by approaching reparations as either rights or symbols. In contrast to the dominant, individual rights-based model, I conclude that understanding reparations as a process best achieves a reconciliation between activist approaches to reparations and theories of justice.

\section{GENDER AND CONFLICT}

Gender roles structure human interaction in times of war and peace and inform political, legal, and cultural responses to the task of peace-building. The trope of men fighting war on the front and women and children staying safe at home does not reflect the reality of war. War comes to civilians, targeting them in their cities, villages, fields, and homes. Only five percent of casualties in the First World War were civilians, whereas civilians accounted for up to 90 percent of casualties in the

4 Here, I refer to feminist theoretical methods discussed in: Mari Matsuda, "When the First Quail Calls: Multiple Consciousness as Jurisprudential Method" (1989) 11 Women's Rights Law Review 7; Maria C Lugones \& Elizabeth V Spelman, "Have we got a theory for you! Feminist theory, cultural imperialism, and the demand for 'the woman's voice'" (1983) 6:6 Women's Studies International Forum 573; Brenda Cossman, "Turning the Gaze back on Itself: Comparative Law, Feminist Legal Studies, and the Post-colonial Project" (1997) 2 Utah Law Review 525.

5 Nicola Lacey, Unspeakable Subjects: Feminist Essays in Legal and Social Theory (Oxford: Hart Publishing, 1998) at 13.

6 Chandra T Mohanty, "Under Western Eyes: Feminist Scholarship and Colonial Discourses" in Chandra T Mohanty et al, eds, Third World Women and the Politics of Feminism (Bloomington, IN: Indiana University Press, 1991) 51.

7 Amani El Jack, Gender and Armed Conflict: Overview Report (Brighton: Institute of Development Studies, 2003) at 9. 
1990s. ${ }^{8}$ Forced displacement, sexual violence, and abduction into fighting forces are common civilian experiences in wartime. ${ }^{9}$ Women and men experience wartime violence differently. Sexual violence is largely inflicted on women, although men and boys are sometimes victims too. Men usually fight the wars, while the majority of women do not take up arms. ${ }^{10}$

Narratives about masculinity and femininity pervade our understandings of conflict. Armed conflict propagates a hyper-masculinized understanding of what it means to be a man (soldier-citizen) and a hyper-feminized understanding of what it means to be a woman (nurturing mother and symbol of the nation). ${ }^{11}$ These expressions of heteronormative gender identity damage both men and women: men (often) die in war, women (sometimes) survive rape and take care of the young, injured, and elderly. Non-conforming gender identities are rendered invisible by these constructions. ${ }^{12}$ Women and girls may voluntarily join or be forced into armed groups. Men and boys are sometimes victims of sexual violence; others may refuse to fight and be ostracized as cowards. Gender is part of the architecture of conflict.

Conflict increases and exacerbates pre-conflict forms and levels of violence against women. ${ }^{13}$ As communities break down during conflict, intimate partner violence increases. Women are also exposed to new forms of violence, as victims of rape by soldiers, occupying armed forces, or peacekeepers. ${ }^{14}$

Being 'safe at home' in times of peace is a reality that few women experience, given the prevalence of domestic violence. On average, at least one in three women is exposed to intimate partner violence in the course of their lifetimes. For this reason, feminists challenge the line between peace and conflict. Though the warring sides may have declared peace, women experience forms of violence on a continuum only partially addressed, or not at all, by cease fires and peace processes. $^{16}$

Feminist research on sexualized violence in conflict has demonstrated the connections between the acceptance of domestic violence and the use of rape as a weapon of war. ${ }^{17}$ Survivors and domestic violence support centres have witnessed this continuity, as the rates of domestic violence have increased with periods of

United Nations, "Women, Peace and Security: Study submitted by the Secretary-General pursuant to Security Council resolution 1325" (2000). ["Women, Peace"]

Ibid at para 4.

10 Sheila Meintjes, Anu Pillay \& Meredeth Turshen, eds, The Aftermath: Women in Post-conflict Transformation (New York: Zed Books, 2002) at 6.

11 Kimberly Theidon, "Reconstructing Masculinities: The Disarmament, Demobilization, and Reintegration of Former Combatants" (2009) 31 Hum Rts Q 1 at 3.

El Jack, supra note 7 at 6.

Meintjes et al, supra note 10 at 4.

El Jack, supra note 7 at 16.

5 UN Division for the Advancement of Women, Background note on "Forms, consequences and costs of violence against women", 9 October 2006 ["Forms"].

16 Theidon, supra note 11 at 31.

17 Caroline ON Moser \& Fiona C Clark, eds, Victims, Perpetrators or Actors? Gender, Armed Conflict and Political Violence (London: Zed Books, 2001). 
militarization in Northern Ireland, Croatia, and the United States. ${ }^{18}$ Other research has uncovered the parallels between torture techniques used in Latin American prisons and patterns of child abuse. ${ }^{19}$

The enormous upheavals of armed conflict sometimes produce disruptions in gender roles. The absence of men and boys from families and communities can result in women and girls taking on new roles, skills, and status. Although conflict can create a space for temporary redefinition of gender relations, very few equality gains are sustained. ${ }^{20}$ Women are frequently told that their claims for equality must wait, with the implication that government policies to undermine patriarchy could destabilize a fragile peace. ${ }^{21}$ According to Franke, "rebuilding post-conflict societies is almost inevitably a process of re-masculinization." 22 Some researchers attribute high levels of domestic violence in post-conflict periods as an attempt to re-establish "normal" pre-war gender relations. ${ }^{23}$ For example, gender-related violence remains common in post-conflict Rwanda. ${ }^{24}$ Community violence (ranging from verbal obscenities to physical violence) seems particularly targeted at literate, educated, employed women in the public sphere, suggesting that violence may be a way to protest women's emancipation. ${ }^{25}$ Any sustained changes for women tend to occur at the micro-level. For example, women's associations, formed during conflict for mutual support, will sometimes evolve into peacetime women's organizations.

The laws of war and the business of peace negotiations push gender to the sidelines. ${ }^{26}$ Women activists have tried to put gender on the agenda, by talking about women's experiences in wartime. ${ }^{27}$ There has been some headway, as international law and transitional justice processes now recognize sexual violence in war as an issue. Much attention has been devoted to ensuring that sexual violence crimes are punished by national and international criminal justice systems, $^{28}$ truth commissions are gender-sensitive, ${ }^{29}$ and disarmament and

18 Liz Kelly, "Wars Against Women: Sexual Violence, Sexual Politics and the Militarised State" in Susie Jacobs, Ruth Jacobson \& Jennifer Marchbank, eds, States of Conflict: Gender, Violence and Resistance (London: Zed Books, 2000) 45; see also, Cynthia Grant Bowman, "Theories of Domestic Violence in the African Context" (2003) 11 Am U J Gender Soc Pol'y \& L 847 at 856.

19 Ibid.

20 United Nations, "Women, Peace" supra note 8 at para 55.

21 Nahla Valji, "Gender Justice and Reconciliation" (2007) online: Friedrich Ebert Stiftung <http://library.fes.de/p-df-files/iez/05000.pdf> at 7.

22 Katherine M Franke, "Gendered Subjects of Transitional Justice" (2006) 15:3 Colum J Gender \& L 813 at 824 .

23 Tristan Anne Borer, "Gendered War and Gendered Peace: Truth Commissions and Postconflict Gender Violence: Lessons From South Africa" (2009) 15(10) Violence Against Women 1169 at 1172; see also Meintjes et al, supra note 10.

24 Heidy Rombouts, "Women and Reparations in Rwanda: A Long Path to Travel" in Ruth RubioMarin, ed, What Happened to the Women: Gender and Reparations for Human Rights Violations, (New York: Social Science Research Council, 2006) at 206 [Rombouts, 2006].

25 Ibid.

26 Bell \& O'Rourke, supra note 3 at 24.

27 Cynthia Cockburn, From Where We Stand: War, Women's Activism and Feminist Analysis (London: Zed Books, 2007).

28 Kelly Dawn Askin, War Crimes Against Women: Prosecution in International War Crimes Tribunals (The Hague: M Nijhoff Publishers, 1997); Rhonda Copelon, "Gender Crimes as War 
demobilization programs address women's experiences as conflict actors. ${ }^{30}$ There are nascent efforts for a gender-just approach for reparations. These gains are very limited, however. Putting sexual violence on the agenda has not led to a recognition that gender norms - of masculinity and femininity - are central to war and peace. ${ }^{31}$ Human security is a deeply gendered phenomenon.

\section{THE DOMINANT APPROACH TO REPARATIONS FOR VICTIMS}

For many victims and survivors struggling to put their lives back together after brutal conflict, reparations may be the policy decision with the most direct impact on their day-to-day lives. In order to begin articulating an approach to reparations that is conscious of gender, the next section will discuss the dominant approach to reparations in the transitional justice field.

Reparations occupies a wide analytical and practical field: it is an element of international law and a key feature of many countries' political and legal responses to conflict. The international regimes on state responsibility, human rights, and criminal law and domestic criminal, civil, and regulatory law may be involved in a country's reparations decisions. The term "reparations" has two main uses: a broad juridical term, chiefly used in international law, which covers all forms of redress for harms suffered as a consequence of certain crimes, and a narrower term to describe administrative programs which attempt to provide benefits directly to certain victims. ${ }^{32}$

Norms and practice in law and policy have centred on developing and strengthening a framework for reparations based on individual rights. This can be seen in international law, human rights law, international criminal law, and UN guidelines.

\section{A. State Responsibility as a Source of Reparations}

Under international law, a wrongful act is conduct, attributable to the state, in breach of the state's international obligations. ${ }^{33}$ Reparation by the state must, as far as possible, wipe out the consequences of the illegal act and re-establish the situation which would have existed but for the wrongful act. ${ }^{34}$ However, the obligations under international law are obligations between states, not obligations between states and individuals, and reparations are paid to the injured state, not to

Crimes: Integrating Crimes Against Women into International Criminal Law" (2000) 46 McGill L J 217.

29 Vasuki Nesiah, ed, "Truth Commissions and Gender: Principles, Policies, and Procedures" (New York: International Center for Transitional Justice, 2006).

30 Theidon, supra note 11.

31 Catherine O'Rourke, “The Shifting Signifier of 'Community' in Transitional Justice: A Feminist Analysis" (2008) 23 Wisconsin Journal of Law Gender \& Society 269 at 284.

32 Pablo de Greiff, "Justice and Reparations" in Pablo de Greiff, ed, The Handbook of Reparations (New York: Oxford University Press, 2006) 451 at 452 [de Greiff, 2006].

33 Draft Articles on Responsibility of States for Internationally Wrongful Acts, Report of the International Law Commission, UN GAOR, 56th Sess., Supp. No. 10. UN. Doc A/56/10, chp.IV.E.1, (2001) at Art 31(1).

34 Case Concerning the Factory at Chorzow (Claim for Indemnity) (Merits), [1928] PCIJ, ser. A, No. 17 at $47-48$. 
the individual. ${ }^{35}$ Where large numbers of victims have been harmed by the wrongful conduct of a state, victims' reparations claims have been settled by claims commissions or arbitral tribunals. Resistance to an individual right to reparations remains commonplace. For example, in 1995 and 2002, Japan's Tokyo District Court denied compensation to Chinese nationals for atrocities suffered during World War II, on the basis that a state is under no obligation to pay damages to individuals of another state when that state has infringed its obligations under international law.

The UN Compensation Commission [UNCC] represents a departure from traditional application of the state responsibility rules denying individual rights to reparation. ${ }^{37}$ Following the ousting of Iraq from Kuwait in 1991, the UN Security Council established the UNCC to process claims and pay monetary compensation for losses during the invasion and occupation of Kuwait. The UNCC has the effect of giving individuals limited standing to apply for reparations for breaches of international obligations. Compensation was not provided to injured states, as in the classical framework on state responsibility, but directly to individuals and corporations.

\section{B. International Human Rights Law: Treaty-based Recognition of Right to Reparations}

The right to redress is enshrined in some international and regional human rights instruments. The International Covenant on Civil and Political Rights $[I C C P R]$ provides the right to a remedy, ${ }^{38}$ but this remedy consists of procedural rights and obligations, like the duty of the state to investigate the violation. ${ }^{39}$ In contrast to the ICCPR, the Convention on the Elimination of all forms of Racial Discrimination and the Convention against Torture provide for a specific right to reparation. $^{40}$ However, none of the bodies monitoring compliance with these treaties has legal competence to order reparations. They do not create a right which can be invoked directly at the international level by an individual. ${ }^{41}$ Thus, the international human rights framework around reparations is still built around rights and obligations among states.

In contrast to the international human rights treaties, regional human rights treaties may give an individual standing in international law to claim a right of reparation. Article 50 of the European Convention on Human Rights and Article

35 Antonio Cassese, International Law (Oxford: Oxford University Press, 2001) at 48.

36 Ilaria Bottigliero, Redress for Victims of Crimes under International Law (Leiden: Martinus Nijhoff Publishers, 2004) at 85.

37 Ibid at 89-95.

38 International Covenant on Civil and Political Rights, GA Res 2200A (XXI), UN GAOR, 21st Sess., Supp. No. 16, at 52, UN Doc. A/6316 (1966), 999 UNTS 171, Arts 2, 3.

39 Bottigliero, supra note 36 at 116-123.

40 Convention on the Elimination of All Forms of Racial Discrimination, Dec. 21, 1965, 660 UNTS

195, Art. 6; Convention Against Torture and Other Cruel, Inhuman or Degrading Treatment or Punishment, G.A. Res. 39/46, UN GAOR, 39th Sess., Supp. No. 51, at 197, UN DOC A/39/51 (1984), Art. 14.

41 Riccardo Pisillo-Mazzeschi, "International Obligations to Provide for Reparations Claims?" in Albrecht Randelzhofer \& Christian Tomuschat, eds, State Responsibility and the Individual: Reparation in Instances of Grave Violations of Human Rights (The Hague: Martinus Nijhoff Publishers, 1999) 149 at 171. 
63(1) of the American Convention on Human Rights create the possibility that an international court might directly require a wrongful state to make reparations to the injured individual. ${ }^{42}$ A landmark decision of the Inter-American Court argued that the individual's right of reparation extended beyond the domestic state's provisions for reparation, thus suggesting an independent individual right of reparation not defined or mediated by the state. ${ }^{43}$ Like the Inter-American Court, the European Court of Human Rights has affirmed that the right to a remedy includes compensation and procedural rights. ${ }^{44}$ However, the European Court's awards for reparations have been more limited than those given by the InterAmerican Court, as they have not ordered rehabilitation, clearance of victims' names, or initiation of investigations.

\section{International Criminal Law}

Contemporary mechanisms of international criminal adjudication have included recognition of victims' right to redress. The Statutes of the International Criminal Tribunals for Yugoslavia and Rwanda contained a limited recognition of an individual's right to reparations, while the Rome Statute of the International Criminal Court [ICC] has gone further.

The Statutes of the International Criminal Tribunal for Rwanda [ICTR] and International Criminal Tribunal for Yugoslavia [ICTY] permit the Tribunals to order only one form of victim redress: the restitution of unlawfully taken property. ${ }^{45}$ The unlawful taking of property must be associated with a crime under the Statute and must be the object of a specific finding in the judgment. ${ }^{46}$ The final judgments of the ICTY and ICTR have not issued a single restitution order nor referred compensation matters to a national body. ${ }^{47}$

Faced with criticisms that the Tribunals were participating in denying victims' rights to redress, Carla del Ponte, (then) Prosecutor of the ICTY and the ICTR, called for a more efficient system for victim compensation. ${ }^{48}$ However, the Security Council and the Judges of both tribunals opposed this suggestion, arguing that the additional workload to deal with reparations claims would negatively impact the tribunals' ability to prosecute accused, would be impossible in practical

\footnotetext{
42 Ibid.

43 Velásquez Rodríguez Case, Reparations (Honduras) (1999) Inter-Am Ct HR (Ser. C.) No. 7 at paras 30-31; for more on the IACHR, see Judith Schonsteiner, "Dissuasive Measures and the 'Society as a Whole': A Working Theory of Reparations in the Inter-American Court of Human Rights" (2007) 23(1) Am U Int'l L Rev 127.

44 Aksoyv Turkey (1996) 23 Eur HR Rep 553 at para 98.

45 Statute of the International Tribunal for the Prosecution of Persons Responsible for Serious Violations of International Humanitarian Law Committed in the Territory of the Former Yugoslavia since 1991, S.C. Res. 827, UN SCOR, 48th Sess., 3217th mtg., Annex, UN Doc S/827 (1993), Art. 24(1) [ICTY Statute]; Statute of the International Criminal Tribunal for the Prosecution of Persons Responsible for Genocide and Other Serious Violations of International Humanitarian Law Committed in the Territory of Rwanda and Other Such Violations Committed in the Territory of Neighboring States, S.C. Res. 955, U.N. SCOR, 49th Sess., 3453d mtg., Annex, UN Doc S/955 (1994), Art 23(1) [ICTR Statute].

46 Bottigliero, supra note 36 at 198.

47 Ibid at 202-203.

48 Carla del Ponte, "Address to the UN Security Council by Carla del Ponte, Prosecutor of the ICTY and ICTR" 21 November 2000, ICTY Doc. JL/P.I.S./542-e of 24 November 2000.
} 
terms, and could lead to unfairness, as only those victims whose perpetrators were tried by the Court would be eligible for compensation. ${ }^{49}$

In spite of this consistent stance of the Judges of the tribunals, the former Registrar of the ICTR initiated a modest assistance program targeted at witnesses and potential witnesses. The program provided legal assistance, housing, and psychological assistance, via Rwandan women's NGOs. The most infamous project, the construction of a peace village in Taba, was designed to give something back to the women from Taba who had testified in the watershed Akayesu trial (in which rape was recognized as an act of genocide). ${ }^{50}$ The program was a token recognition of the need for reparations for victim-witnesses, but it was roundly criticized. In Rwanda, critics complained that only $50 \%$ of the promised amounts were transferred, and that the selection of people for the 23 houses built in Taba was unfair. At the UN level, the Security Council was concerned that the Statute of the ICTR did not allow this type of social assistance program, and so the program was officially closed in December $2001 .^{51}$

In a marked departure from the reticence of the ad hoc international criminal tribunals, the Statute of the International Criminal Court recognizes the right of victims to obtain individual reparations and provides mechanisms for this purpose. The vastly expanded capacity of the ICC to award reparations resulted from lobbying by women's groups and victims' rights groups and some State delegations during the 1998 Rome Conference. ${ }^{52}$

Once an individual is found guilty of a crime under the ICC's jurisdiction, the Court has the power to determine the scope and extent of damages, losses, and injuries suffered by victims. ${ }^{53}$ This can occur either through a request from victims or on the Court's own motion. The Court may make an order directly against the convicted person or may order that the award be made through the ICC Trust Fund for Victims. Reparations may be awarded in the form of restitution of property, compensation, rehabilitation, or other forms. Thus, the emergence of an individual right to reparation can be observed in international criminal law.

\section{UN Standards and Norms}

Alongside the development of a right to reparations in international human rights treaties and international criminal law, soft-law, non-binding instruments have stressed the importance of reparations for victims of human rights violations. The most comprehensive attempt to develop a body of principles around reparations occurred under the auspices of the Commission on Human Rights. Through the efforts of two rapporteurs (Theo van Boven and Cherif Bassiouni), the Commission of Human Rights agreed the "Basic Principles and Guidelines on the Right to a Remedy and Reparation for Victims of Gross Violations of

\footnotetext{
49 Bottigliero, supra note 36 at 206.

50 Prosecutor v Akayesu, Case No. ICTR-96-4, Judgment (Sept. 2, 1998).

51 Heidy Rombouts, Victim Organisations and the Politics of Reparation: A Case-Study on Rwanda (Antwerp: Intersentia, 2004) at 464-466 [Rombouts, 2004].

52 Naomi Roht-Arriaza, "Reparations Decisions and Dilemmas" (2004) 27 Hastings Int'l \& Comp L Rev 157 at 168.

53 Rome Statute of the International Criminal Court, UN Doc A/CONF.183/9 (1998), Art 75.
} 
International Human Rights and Serious Violations of International Humanitarian Law" [BPG] at its April 2005 session. ${ }^{54}$

The document takes a broad approach to remedy and reparations, incorporating the obligations to prevent violations, investigate and prosecute violations, and provide effective remedies to victims. ${ }^{55}$ Remedies to victims include equal and effective access to justice, adequate, effective and prompt reparations, and access to relevant information concerning violations and reparations mechanisms. ${ }^{56}$ The numerous forms of reparations are well described in the BPG: restitution, compensation, rehabilitation, satisfaction, and guarantees of non-repetition. ${ }^{57}$ This is helpful in widening the scope of reparations beyond the common idea that reparations and compensation are synonymous.

Restitution aims at restoring the victim to the original situation before the violation occurred, and it includes return to one's place of residence, restoration of employment, return of property, and restoration of liberty, enjoyment of human rights, identity, and citizenship. This affords the concept of restitution breadth beyond the return of property. Compensation provides monetary and in-kind payment for harm that can be economically assessed. Harm includes physical or mental harm, lost opportunities (for employment and education), material damage, harm to reputation and dignity, moral damage, and costs required for assistance and medical and psychological services. Rehabilitation incorporates medical and psychological care and legal and social services. Satisfaction includes cessation of continuing violations, verification of facts and disclosure of truth, official apologies, commemorations, and inclusion of accounts of the violations in educational materials. The last category, guarantees of non-repetition, includes measures aimed to prevent reoccurrence of rights violations such as measures to ensure civilian control of the military, strengthen the judiciary's independence, and prevent social conflict.

\section{E. Conclusion}

This review of the international legal framework for reparations demonstrates that the normative tide has been towards the recognition of an individual right to reparations for victims of gross violations of human rights. The consensus blurs around how that right should be realized. The classical rules on state responsibility and the approach of international human rights treaties acknowledge the right to reparation but permit it to be claimed only via domestic channels. More recent developments in international human rights and criminal law recognize individual standing at international law to claim reparations. The jurisprudence of the InterAmerican Court of Human Rights has recognized a right to reparation and made orders against states for that right to be realized. Most recently, flanked by the new Basic Principles and Guidelines, the establishment of the ICC's Trust Fund for Victims provides a clear indication of the international community's recognition of an individual victim's right to reparation.

\footnotetext{
54 Basic Principles and Guidelines on the Right to a Remedy and Reparation for Victims of Gross Violations of International Human Rights and Serious Violations of International Humanitarian Law, UN Human Rights Committee, 56th meeting, chap. XI, E/CN.4/2005/L.10/Add.11 [BPG]. 


\section{WOMEN'S VOICES ON REPARATIONS}

A relatively clear understanding exists in international law and transitional justice circles about the definition of reparations and its contours. The most progressive position, though not universally accepted, is that an individual has a right to reparations. The paradox is that this rights-based approach does not match the approach to reparations among many activists. The following section outlines how some women activists talk about reparations, in order to demonstrate the gap between the dominant rights-based approach and activist discourses.

Every conflict is different, and the needs of survivors vary enormously within conflict societies and from conflict to conflict. Women who live through conflict are very different from one another and do not constitute a single group in reality. Nonetheless, a comparative analysis of women's attitudes about reparations in a number of societies emerging from conflict reveals some interesting trends. These trends are presented at a macro, generalized level that makes no attempt to reflect the detailed political, historical, economic, and social contexts in which these claims are articulated. The following analysis is based on a number of sources.

As part of its project on reparations, the International Center for Transitional Justice [ICTJ] initiated a project on gender and reparations. The first part of the study, produced through two years of on-the-ground case studies, centred on empirical gender analyses of reparations programs in Guatemala, Peru, Rwanda, Sierra Leone, South Africa, and Timor-Leste.

In parallel to this project, the Coalition on Women's Human Rights in Conflict Situations is engaged in a research action project with activists on gender and reparations. ${ }^{59}$ The Coalition conducted a study that included interviews with activists in South Africa, Rwanda, Sierra Leone, Guatemala, Peru, Chile, and Timor-Leste. ${ }^{60}$ At an international meeting hosted by the Coalition and the Urgent Action Fund-Kenya, women's rights advocates and activists, as well as survivors of sexual violence in situations of conflict, from Africa, Asia, Europe, Central, North, and South America, issued the Nairobi Declaration on Women's and Girls' Right to a Remedy and Reparation. ${ }^{61}$ The Declaration was signed by the organizations present at the meeting. ${ }^{62}$ Many of the activists interviewed in the first

58 Ruth Rubio-Marin, What Happened to the Women: Gender and Reparations for Human Rights Violations (New York: Social Science Research Council, 2006).

59 The author is a member of the Coalition and was present at the Nairobi Meeting.

60 Vahida Nainar, "Women's Right to Reparation” (Paper delivered at the International Meeting on Women's Right to Reparation, Nairobi, March 2007) [unpublished].

61 "Nairobi Declaration on Women's and Girls' Right to a Remedy and Reparation," adopted March 2007, online: Womens' Rights Coalition <http://www.womensrightscoalition.org/ site/ reparation/signature_en.php>.

62 Signatories to the Declaration: Coalition for Women's Human Rights in Conflict Situations; Urgent Action Fund-Africa, Kenya; Rights \& Democracy, Canada; Alianza de Mujeres Rurales por la Vida, Tierra y Dignidad, Guatemala; ASADHO/Katanga - Association africaine de défense des droits de l'Homme, section Katanga, Democratic Republic of Congo; Asociación Reflexión de Inocentes Liberados, Peru; Association des femmes juristes, Burundi; CCJT - Coalition congolaise pour la justice transitionnelle, Democratic Republic of Congo; CDA - Community Development Centre, Sudan; CEDA - Community Extension Development Association, Sierra Leone; CLADEM - Comité de América Latina y El Caribe para la Defensa de la Derechos de la Mujer, Peru; ODEPU - Corporación de Promoción y Defensa de los Derechos del Pueblo, Chile; Coordinadora Nacional de Mujeres Afectadas por la Violencia Política, Peru; Corporación Humanas, Chile; Corporación para la Vida Mujeres que Crean, Colombia; Demus - Estudio para 
phase of the Coalition's project attended the conference held in Nairobi. The draft of the civil society declaration on gender and reparations was developed from analysis of the report's interviews with activists. Through plenary and subcommittee sessions, the participants extensively revised the draft to produce a Declaration that represented the Conference's views.

In the following section, findings from the Coalition's background research and the interventions from participants in the Nairobi meeting will be integrated into a broader analysis that includes the ICTJ study. I then analyze the Nairobi Declaration as one expression of women's views on gender and reparations.

\section{A. Thematic Analysis of Reparations Priorities 1. Broad Scope of Eligibility for Reparations}

When provided the opportunity to talk about what they need from transitional justice, it is common for women to articulate the needs of their families or the harms experienced by members of their families. For example, women testifying before the truth commissions in South Africa and Peru tended to downplay or omit their harsh treatment and focus on what happened to their male relatives. ${ }^{63}$ Thus, it was useful that the definition of those eligible for reparations included relatives or dependants of victims. A strength of the UNCC in Kuwait was its inclusive approach to the definition of victims. For claims of loss by individuals, individual victims included victims related to a primary victim, either as spouses, children, or parents. ${ }^{64}$ Compensation was available for death of a spouse, child, or parent resulting from the invasion. ${ }^{65}$ In lobbying around the creation of the International Criminal Court, the Women's Caucus for Gender Justice argued for an inclusive definition of victim in reparations: "compensation should be made available to the families of victims ... dependents, and others having a special relationship with the direct victims, whether or not formally recognized at law in the national system." ${ }^{66}$ The effect is that women's voices have contributed to a broad definition of the class of people eligible to benefit from reparations programs.

la defensa y los derechos de las mujeres, Peru; ESSAIM - Cadre de concertation et d'activités pour la protection et la défense des droits des femmes à l'est de la République démocratique du Congo, Democratic Republic of Congo; Feinstein International Center, Tufts University, USA; FOKUPERS - East Timorese Women's Communication Forum, Timor Leste; Grupo Suporta Inan, Timor Leste; Instituto de Estudios Comparados en Ciencias Penales, Guatemala; International Women's Human Rights Law Clinic, CUNY Law School, USA; Khulumani Support Group, South Africa; LDGL - Ligue des droits de l'Homme dans la région des GrandsLacs, Rwanda; Mamá Maquín, Guatemala; MARWOPNET - Mano River Women Peace Network, Sierra Leone; PAIF - Programme d'appui aux initiatives féminines, Democratic Republic of Congo; PCS - Consejería en Proyectos, Latin America; REDRESS, United Kingdom; Ruta Pacifica de las Mujeres, Colombia; SEVOTA - Solidarité pour l'épanouissement des veuves et des orphelins visant le travail et l'auto-promotion, Rwanda; SOFEPADI - Solidarité féminine pour la paix et le développement intégral, Democratic Republic of Congo; Women's Forum, Sierra Leone; Women's Research and Action Group, India.

Beth Goldblatt, "Evaluating the Gender Content of Reparations: Lessons from South Africa" in Rubio-Marin, supra note 58, 48 at 55; Julie Guillerot, "Linking Gender and Reparations in Peru: A Failed Opportunity” in Rubio-Marin, ibid at 146.

64 Judith G Gardam \& Michelle J Jarvis, Women, Armed Conflict, and International Law (The Hague: Kluwer Law International, 2001) at 234. Ibid at 237.

66 Women's Caucus for Gender Justice in the International Criminal Court, "Part III: Recommendations and Commentary for the March 1998 PrepCom, Reparations" (18 Mar 1998), online: Women's Initiatives for Gender Justice <http://www.iccwomen.org/index.php.>. 


\section{Defining Harm in a Gendered Way}

As war is gendered, the definition of harms which are the basis for eligibility has gendered effects. In South Africa, the Truth and Reconciliation Commission's [TRC] definition of victims was based on "harm as a result of a gross violation of human rights or an act associated with political objectives for which amnesty has been granted." ${ }^{67}$ This definition was criticized for its exclusion of the victims of such apartheid policies as forced removals, pass laws, and residential segregation. ${ }^{68}$ The focus on gross human rights violations and "political crimes" excluded the structural social and economic violence which imperiled day-to-day subsistence under apartheid. ${ }^{69}$ As women have traditionally been responsible for subsistence (food, care, and shelter), the exclusion of these harms rendered women's experiences of apartheid less visible. Even for events which fell under the umbrella of the TRC, ideologies functioned to deny women's experiences of the conflict. For example, in one case, the TRC's Amnesty Committee rejected the notion that a sexual crime could be politically motivated, in effect denying that a woman could have been raped just because she was from another political party. ${ }^{70}$ The question of whether rape could be considered a "political" act was contentious even within the feminist community. ${ }^{71}$ Similarly, Chile's decision to define victims as those killed or "disappeared" excluded the significantly larger number of torture survivors or those forced into exile. ${ }^{72}$

In contrast, the UNCC's approach to the definition of compensable harms resulted in the recognition of women's experiences during the invasion of Kuwait. Being forced to flee was in itself recognized as leading to compensable harm, as were injuries sustained in refugee camps. ${ }^{73}$ This is an important advancement, as women disproportionately figure in the populations forced to flee during conflict. The UNCC also made important strides in recognizing sexual violence as a serious personal injury, compensable on a par with aggravated assault and torture. ${ }^{74}$ Mental anguish resulting from sexual assault and miscarriage, unwanted abortion, or still-births following invasion were included as compensable harms, thus further recognizing women's experiences of the conflict.

\section{Root Causes and Continuity of Violence}

Participants at the Nairobi Meeting came to the emphatic conclusion that returning victims to the point they were in before the conflict is not an understanding of reparations that can work if one is concerned with a gendersensitive approach to reparations. Activists from South Africa, Darfur, Peru, Sierra

\footnotetext{
67 Lovell Fernandez, "Reparation for Human Rights Violations Committed by the Apartheid Regime in South Africa" in Albrecht Randelzhofer \& Christian Tomuschat, eds, State Responsibility and the Individual: Reparation in Instances of Grave Violations of Human Rights (The Hague: Martinus Nijhoff Publishers, 1999) 173 at 176.

68 Roht-Arriaza, supra note 52 at 178.

69 Pumla Gobodo-Madikizela, "Women's Contributions to South Africa's Truth and Reconciliation Commission" (Boston: Women Waging Peace Policy Commission, 2005) at 14.

70 Priscilla Hayner, Unspeakable Truths: Confronting State Terror and Atrocity (New York: Routledge, 2001) at 80.

71 Nesiah, supra note 29 at 27.

72 Roht-Arriaza, supra note 52 at 178.

73 Gardam \& Jarvis, supra note 64 at 240.

74 Ibid at 238
} 
Leone, and Rwanda called attention to the discriminatory laws and practices which denied women's rights. For example, one Nairobi Meeting participant argued that reparations decisions in Darfur must consider that women had no rights to the land before the conflict. A similar concern was found by ICTJ's researchers in Guatemala: indigenous women's organizations argued that the material restitution component of reparations would not help women because they were denied rights to own land before the conflict.

The conclusion that reparations cannot be about restitution to pre-conflict conditions leads many women to articulate a theory of reparations that calls for understanding and addressing the root causes of the conflict. This could be seen at the Nairobi Meeting in the interventions of activists from South Africa, Burundi, and Argentina.

In some cases, interrogating the root causes of conflict as part of the goals of reparations leads women to draw connections between pre and post-conflict forms and levels of violence against women. Activists in Peru and Argentina, for example, argued at the Nairobi Meeting that there is continuity between violence today and violence under the dictatorships. However, other studies have found that activists are not drawing connections between gender violence in the conflict and present-day violence. Though South Africa has endemic violence against women, women's organizations have not often linked past sexual crimes to current sexual crimes. ${ }^{76}$ A similar pattern was observed in Peru and Guatemala, as the feminist organizations concerned with violence against women focused very little on "political violence", and human rights organizations ignored women's experiences of the conflict.

\section{Compensation}

Money helps to relieve some of the burdens caused by human rights violations, and women survivors will often articulate monetary compensation as one element of reparations. Participants from Rwanda and Peru in the Nairobi Declaration meeting argued that compensation for economic losses should be included in reparations programs, particularly as many women will have lost male breadwinners or the means of making a living. Victims in Sierra Leone asked for individual monetary compensation as one aspect of their understanding of reparations. ${ }^{78}$ Through interviews with women from civil society organizations in Timor-Leste, researchers learned that one priority (among many) was some form of material support for survivors of the conflict. ${ }^{79}$ In South Africa, many of those who gave testimony to the Truth and Reconciliation Commission were disappointed to learn that it had no immediate power to help with day-to-day

75 Claudia Paz y Paz Bailey, "Guatemala: Gender and Reparations for Human Rights Violations" in Rubio-Marin, supra note 58 at 110.

79 Galuh Wandita, Karen Campbell-Nelson \& Manuela Leong Pereira, "Learning to Engender Reparations in Timor-Leste: Reaching Out to Female Victims" in Rubio-Marin, supra note 58 at 300. 
survival needs or with basic physical rehabilitation. ${ }^{80}$ Those who did eventually receive Urgent Interim Reparations awards from the South African government felt that the amounts given were of no use to their pressing material survival needs. ${ }^{81}$ The award of a monetary compensation is not the only issue at stake, as the ability to choose how to utilize that award is also a concern. In South Africa, the money has helped to give women some status and independence. ${ }^{82}$ In Rwanda, Avega, the Association for Genocide Widows, advocated for monetary reparations as this would allow survivors to choose how to spend their award. ${ }^{83}$

The limitations of understanding reparations as purely monetary compensation are exemplified by reparation efforts in Latin America. In Latin America, monetary compensation is controversial because many regard these payments as "blood money" intended to silence or deflect attention from larger issues of impunity and recognition. ${ }^{84}$ For example, in Argentina, the Mothers of Plaza de Mayo split into two groups on whether to accept or reject government reparation funds. ${ }^{85}$ Similarly, the "comfort women" in Japan rejected the monetary reparations offered by the Japanese government on the basis that it came from private sources, and not from the government's funds.

\section{Dignity}

A clear common message is the need to go beyond monetary compensation. For example, the "comfort women" rejected the Japanese government's offer of compensation, not because of the amount but because the government did not acknowledge any responsibility. The six women (out of 500) who did accept the funds emphasized that, despite their acceptance, no monetary repayment could repair the harm they had suffered. ${ }^{86}$ In contrast, most Asian-Americans detained by the US government during World War II accepted a small sum $(\$ 20,000)$, arguably inadequate to compensate for their financial and moral losses, because it was offered with an official acknowledgement of responsibility and a government apology. ${ }^{87}$

In addition to the call for an acknowledgement of responsibility, victims have stressed the importance of measures that bear public witness to the crimes committed. For example, in South Africa, it was common for relatives to demand a death certificate for someone disappeared by the regime or a tombstone for a murdered relative. Information about the dead and disappeared and measures to restore the dignity of those wrongly convicted are also common themes in reparations debates in Argentina, according to a participant in the Nairobi Meeting. Similarly, the "comfort women" have demanded that a historical account of what happened to them be included in school textbooks. ${ }^{88}$ In Latin America,

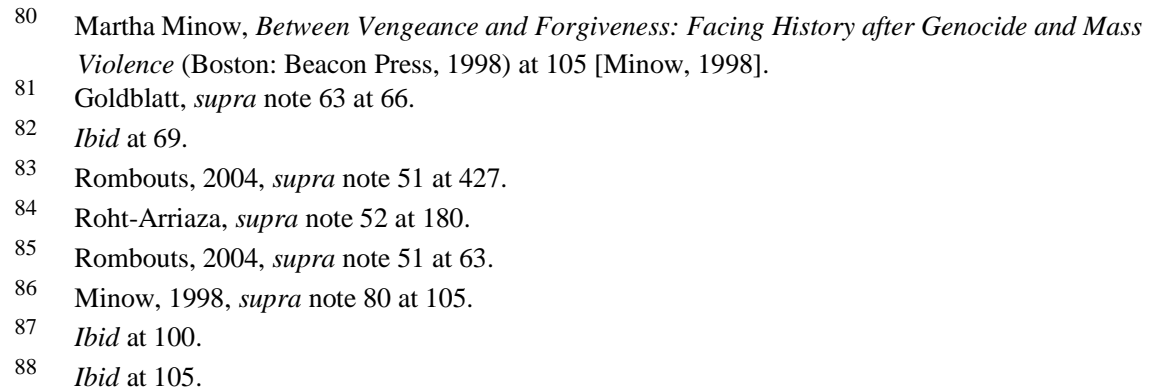


survivors and relatives have called for public monuments to be built and named in honour of the murdered and disappeared. ${ }^{89}$ According to Nairobi Meeting activists who work with victims of sexual violence in Rwanda and Sierra Leone, actions to restore the dignity of sexual violence victims are a crucial component of reparations. This theme also appears in ICTJ's interviews with women from civil society organizations.

\section{Health Services}

Victims articulate reparations claims around their physical and mental health needs. Access to health services appears in the ICTJ's case studies as a reparations claim from women victims in South Africa, ${ }^{91}$ Sierra Leone, ${ }^{92}$ and Timor-Leste. ${ }^{93}$ It is a central concern among survivors of the genocide in Rwanda. ${ }^{94}$ As parts of its reparations program, the government of Rwanda implemented a form of reparations through preferential access to health services. ${ }^{95} 68,000$ medical cards were distributed to rescapés, ${ }^{96}$ permitting them access to medical services for nongenocide and genocide-related issues. In practice, it has contributed to tensions between classes of survivors in Rwanda. Many men and women testify that they no longer dare to use their medical cards because they fear mistreatment and stigma. Doctors and nurses, among others, question why these survivors deserve free medical care, while everyone else has to pay. Although they are eligible for free care, many survivors are instead choosing to pay.

At the Nairobi Meeting, women from Rwanda, Argentina, and Peru called for mental and social counseling to help survivors recover from the conflict, either

\footnotetext{
Guillerot, supra note 63 at 147.

Wandita et al, supra note 79 at 300.

Goldblatt, supra note 63 at 69.

King, supra note 78 at 255.

Wandita et al, supra note 79 at 299.

Rombouts, 2006, supra note 24 at 224.
}

95 Negotiations on the establishment of government reparations programs have been on-going since the genocide in Rwanda. There are two funds: the FARG (Fonds national pour l'assistance aux victims les plus nécessiteuses du genocide et des massacres perpétrés au Rwanda) and the FIND (Fonds d'indemnisation). The FARG provides social assistance to rescapés of the genocide, but it does not provide compensation. The FARG has paid secondary school fees for students who qualify as "needy rescapés", helped to build housing, and provided free medical assistance. The FARG has existed since 1998, while the FIND has been discussed but never established. The FIND is meant to address claims for compensation, as well as extend reparations to a class of beneficiaries beyond the needy rescapés currently included in the FARG fund. The social assistance measures under the FARG will be incorporated into the FIND, which will also fund commemoration activities. Rombouts, 2004, supra note 51 at 371-379.

96 The notion of rescapé is central to Rwandan understandings of eligibility for reparations, but it is complex and multi-faceted. The first aspect of rescapé identity limits the notion of harm to the fact of being pursued, hunted down, or persecuted. The second parameter broaches supposed ethnic-neutrality: most acknowledge that both moderate Hutu and Tutsi were persecuted, and therefore qualify as rescapés, although complexities arise with regard to inter-ethnic marriages. However, victims of RPF crimes are denied rescapé status. The third parameter concerns the belief that presence in the country during the 1994 events is fundamental to being a rescapé. In the fourth parameter family ties, relations, and circumstances play a role in determining rescapé status. This becomes particularly relevant for children and widows of inter-ethnic marriages. Rombouts, 2004, supra note 51 at 201. 
individually or in groups. This fits with a common theme in the ICTJ case studies. ICTJ's studies in Guatemala, ${ }^{98}$ South Africa, ${ }^{99}$ Peru, ${ }^{100}$ and Sierra Leone ${ }^{101}$ note that victims called for psychological reparations measures as a form of reparation. The design and implementation of these measures require careful thought to ensure they respond to the needs of a diverse group of victims. Indigenous women's groups argued for psychosocial counseling in their communities, implemented from the viewpoint of Mayan spirituality and based on respect for knowledge of community elders, including women. ${ }^{102}$ Gender norms influence the design and delivery of counseling programs, and often it is the men who are hardest to reach. Organizations in Guatemala setting up self-help groups found that it was relatively easy to gather women to talk about their feelings, whereas men were much more reluctant to participate. ${ }^{103}$ This problem was also encountered in Rwanda. ${ }^{104}$

\section{Housing}

Housing comes up as a common need among victims in the reconstruction process after conflict. Ninety percent of the victims who gave testimony to the South African Truth and Reconciliation Commission included housing in their requests for reparations. ${ }^{105}$ A subsequent study on how victims used their monetary compensation awards showed that many used it for housing-related costs. ${ }^{106}$ Women's groups interviewed as part of the ICTJ's study in Sierra Leone stressed that housing was a common need of women. ${ }^{107}$ The ICTJ Timor-Leste study included interviews with a sample of 50 female victims across 11 districts. These women listed adequate housing as a component of reparations. ${ }^{108}$ As part of the Rwandan government's reparations efforts, a survey of victims' needs was conducted. ${ }^{109}$ The survey found that 80,000 women and 53,000 men were without shelter. In response, the government built 3000 houses and distributed the homes (often only partially built) as part its FARG program to assist needy rescapés.

\section{Education for Children}

Victims and survivors have also looked to the future in pursuit of reparations for the past. In a multi-country study of Latin American victims, many survivors emphasized the need for education of the children of those killed, disappeared, tortured, or imprisoned. ${ }^{110}$ South African victims demanded that perpetrators pay

\footnotetext{
98 Paz y Paz Bailey, supra note 75 at 112.

99 Goldblatt, supra note 63 at 69.

100 Guillerot, supra note 63 at 148.

101 King, supra note 78 at 255.

102 Paz y Paz Bailey, supra note 75 at 113.

103 Ibid at 112

104 Rombouts, 2006, supra note 24 at 209.

105 Goldblatt, supra note 63 at 59.

106 Ibid at 69.

107 King, supra note 78 at 255.

108 Wandita et al, supra note 79 at 299.

109 Rombouts, 2006, supra note 24 at 222.

110 Roht-Arriaza, supra note 52 at 180, citing a multi-country study conducted by a Chilean human rights organization under the auspices of the Association for the Prevention of Torture.
} 
for the education of victims' children. ${ }^{111}$ They also felt that they should be given preferential access to government programs for their children's education. ${ }^{12}$ Women in Peru called on the government for increased support for children's education. ${ }^{113}$ Discussions in women's groups in Sierra Leone revealed that women felt that the government had an obligation to provide free education to children born as a result of war-time conflict. ${ }^{114}$ In the ICTJ studies in Timor-Leste, education for children came at the top of the list of priorities among women victims, and many used the funds received through the Urgent Reparations program to pay for children's school fees. ${ }^{115}$ In Rwanda, Ibuka, a leading victims' organization, demanded that school fees for all rescapés be provided by the government's reparations program. ${ }^{116}$

Some female victims have criticized the Rwandan government's school fees policy. Women whose children died cannot benefit, and they regret that the fund does not provide any funding for adult education. Some women need their children at home, to help look after them or other sick relatives, or to contribute to incomegenerating activities. In principle, many women will agree that it is right to educate the country's children, but they feel that it drains the resources available to them to survive.

\section{Economic Measures}

In the ICTJ research, a number of case studies point to victims' calls for economic development measures. It is interesting to note that this did not appear in discussions at the Nairobi Meeting. In Timor-Leste, women victims included in their definition of reparations a demand for the government to do something to ensure fair prices for their agricultural products. ${ }^{118}$ Funds disbursed by the government in the form of urgent reparations were used by some of the beneficiaries to launch income-generating activities. ${ }^{119}$ The study in Peru concluded that women mobilized as a way to attract the government's attention to their pressing needs brought about by the violence. Jobs figured high in that list of needs among Peruvian women. ${ }^{120}$ In meetings about reparations in Sierra Leone with urban women, women called for micro-credit facilities and skills training for victims. ${ }^{121}$ Women in rural areas argued that agricultural equipment, transportation, and marketing facilities should be included in the government's reparations efforts. ${ }^{122}$ Women's organizations felt that the government should rehabilitate

\footnotetext{
111 Ibid.

112 Goldblatt, supra note 63 at 71.

113 Guillerot, supra note 63 at 147.

114 King, supra note 78 at 255.

115 Wandita et al, supra note 79 at 299-304.

116 Rombouts, 2004, supra note 51 at 442.

117 Rombouts, 2006, supra note 254 at 223.

118 Wandita et al, supra note 79 at 299.

119 Ibid at 304.

120 Guillerot, supra note 63 at 147.

121 King, supra note 78 at 255.

122 Ibid.
} 
markets to make them accessible to women with disabilities, a concern for the many women who survived amputations in the war.

\section{Women's Rights Reforms}

Attention to pre-existing gender discrimination compels many women to push for reforms to laws, practices, and customs that discriminate against women. Nairobi Meeting participants from Rwanda, Sierra Leone, and Burundi argued that reforming laws on sexual violence and raising awareness on women's rights should be understood as part of government reparations programs. Activists from Peru argued that denial of reproductive rights, like rights to abortion, caused some of the conflict violations, as rapes resulted in forced pregnancies. This injustice continues post-conflict and requires legislative change as part of dealing with the conflict's legacy. Reforms to laws restricting women's rights to own or inherit land were singled out by activists from Darfur. Calls for legal reform also appear in the ICTJ's research, particularly in the Sierra Leone case study, where women advocated reform to laws on domestic violence and inheritance.

\section{Ending Impunity}

For many activists, reparations include a broad understanding of justice. At the Nairobi Meeting, activists from Peru, Rwanda, and Argentina stressed that reparations is incomplete if perpetrators of sexual violence go unpunished. Findings from the ICTJ's study in Timor-Leste echo this demand for justice. ${ }^{125}$

\section{Political Participation of Women in Post-conflict Government}

A further theme found among women in various contexts is an emphasis on political participation of women. At one level, women argue that they must be included in decisions about how reparations programs and policies are designed and implemented. On another level, women are arguing that they must participate in the broader agenda of the post-conflict reconstruction process. They see laws and customs that inhibit women's active participation in public life as part of the transitional justice project and measures to improve women's participation in politics as part of reparations. Activists from Chile, Darfur, Sierra Leone at the Nairobi Meeting called for increased participation of women in the post-conflict politics. Calls for women's participation in transitional justice decision-making signal the efforts of women activists to position women as equal citizens, thus challenging post-conflict reconstruction of patriarchy.

\section{B. Nairobi Declaration on Women's and Girls' Right to a Remedy and Reparations}

With its ambitious scope and improbable sentence constructions, the Nairobi Declaration carries the hallmarks of a document written by committee in the excitement of an international feminist gathering. It provides an invaluable insight into the concerns of activists working for a feminist approach to reparations.

123 Ibid at 260.

124 Ibid at 255 .

125 Wandita et al, supra note 79 at 299. 
The Nairobi Declaration borrows from and pushes beyond international frameworks on the right to reparation. ${ }^{126}$ The Declaration uses many of the terms found in the Basic Principles and Guidelines (restitution, compensation, and reintegration), but the context, tone, and spirit of the Declaration offer a unique civil society perspective. The Declaration begins by adopting a wide definition of harm, as the basis for a claim to reparation. It includes harm to physical integrity, psychological and spiritual well-being, economic security, social status, and the social fabric of the community. Gender identity is understood to be a construction. $^{127}$ The Nairobi Declaration references age and customary and religious law as factors that must be analyzed in understanding diverse needs for reparations.

The Declaration views women as having an important public role in rebuilding and maintaining their families, communities, and societies. This connects to the Declaration's message that the design, implementation, and evaluation of reparations programs must be participatory. Participation of women and civil society organizations in the transitional justice process is essential according to the drafters of the Declaration. ${ }^{128}$ Though the decision-making process should be participatory, the Declaration asserts that the state bears the primary responsibility for reparations. Governments should not undertake development activities instead of reparation, as women and girls risk being excluded from the opportunities provided by development.

The understanding of reparations driving the Declaration is broad. Reparations should include: 1) physical and mental health services and other services for rehabilitation; 2) provisions for compensation and restitution; 3) justice initiatives including ending impunity for sexual violence crimes; 4) programs aimed at restoring victims' dignity using symbolic tools like public apologies; 5) truth telling, including the acknowledgement of women's suffering; 6) educational initiatives, including raising awareness on women's rights and gender sensitivity; and 7) the reform of discriminatory laws and customs against women. ${ }^{129}$

The Declaration has a broad understanding of reparations because the Declaration contains a theory of gender-based violence and a prescription for postconflict social transformation. It argues that gender-based violence in conflict is the result of inequalities between women and men, girls and boys that predate the conflict. These inequalities structure violations during the conflict and are aggravated in the post-conflict period. Because the origins of violations of rights predate the conflict, reparations must aim to transform these socio-cultural injustices and must, by definition, not attempt to restore the victims to their preconflict conditions. The Declaration thus calls for an understanding of reparations that is driven by the goal of social transformation.

126 Valérie Couillard, "The Nairobi Declaration: Redefining Reparations for Women Victims of Sexual Violence" (2007) 1 International Journal of Transitional Justice 444 at 445.

127 Ibid at 449.

128 Ibid at 450.

129 Anne Saris \& Katherine Lofts "Reparation Programmes: A Gendered Perspective" in Carla Ferstman et al, eds, Reparations for Victims of Genocide, War Crimes and Crimes against Humanity (The Hague: Brill, 2008) 79 at 93. 


\section{Conclusion}

Listening to the stories, expectations, and demands of victims compels us to recognize that victims have a very broad understanding of the idea of reparations. It is clearly much more than an individual right to reparations, as understood in international law. According to the research on women's understanding of reparations, it includes the following elements:

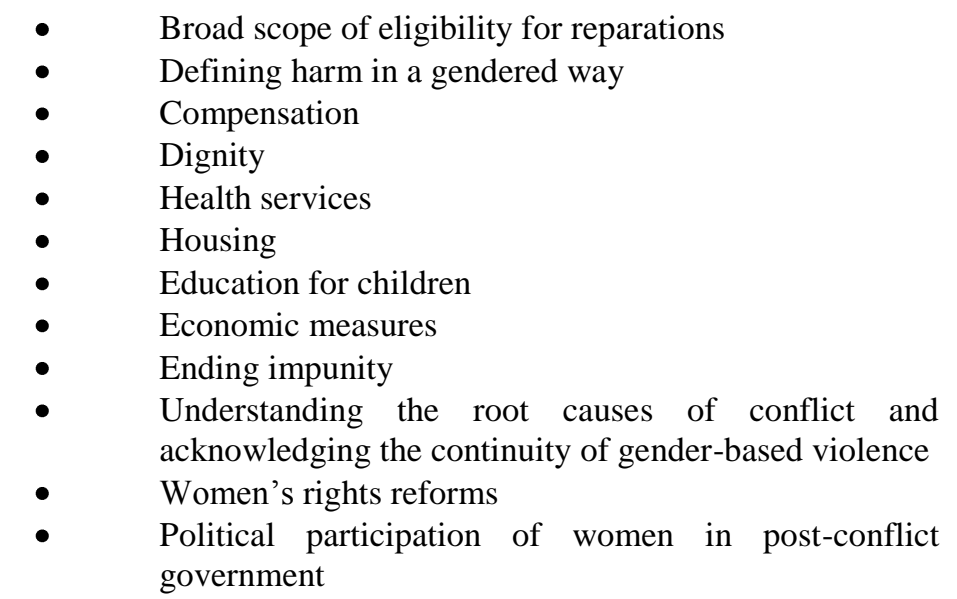

The challenge, then, is to explain why there seems to be such a huge gulf between the normative framework in international law, human rights law, and criminal law and the understanding of reparations developed at the ground-level. The gulf, I argue, is caused by a different normative approach to the meaning of justice. In the next sections, I offer theoretical models for reparations, based on theories of justice, and then elaborate a feminist critique of these models.

\section{THREE THEORETICAL MODELS OF JUSTICE}

The aim of reparations is to achieve justice for victims. But defining justice and the means to achieve it is a much deeper conceptual and practical challenge. Based on work by Nancy Fraser, the following section proposes three models for defining justice. ${ }^{130}$ Each model carries with it a conception of identity and a remedy to injustice.

According to some schools of thought, justice can be defined as "a standard whereby the distributive aspects of the basic structures of society are to be assessed." ${ }^{131}$ If justice is about distribution, then injustice is about imperfect distribution. The "stuff" of distributive justice is material resources, rights and liberties, and opportunities. Other thinkers argue that just distribution should include attention to culture and community. These opposing views all depart from the "justice as distribution" paradigm - the debate is a question about what is

\footnotetext{
130 Nancy Fraser, Justice Interruptus: Critical Reflections on the "Post-socialist" Condition (New York: Routledge, 1997); For an application of Nancy Fraser's framework to transitional justice prosecutions, see Franke, supra note 22.

131 John Rawls, A Theory of Justice (Cambridge: Harvard University Press, 1971) at 9.
} 
distributed and how much. ${ }^{132}$ Another possibility is to step out of the "justice as distribution" paradigm to define "justice as [a] process" that concentrates on action, decisions about action, and provision of the means to develop and exercise capacities.

\section{A. Justice as Distribution of the Material}

In defining justice as distribution, liberal and egalitarian thinkers emphasize distribution to correct socio-economic inequality. This includes not only material resources, but also rights, liberties, and opportunities, which have been constructed as material things. ${ }^{134}$ The liberal paradigm conceives of a right as something one actually has, in a proprietary sense, rather than as creating the conditions for relationships with others. ${ }^{135}$ This line of thought is concerned with socio-economic views of injustice, whereby the solution is egalitarian redistribution. ${ }^{136}$

The "Material distributive justice" strand has the abstract, atomized, neutral, liberal individual at its centre. The good life can be realized by fulfilling the needs of this "empty vessel" individual. Classical liberal thought imagines a preconstituted self: the "self stands at the centre of the world, fully in control of himself, clear about his motives and in possession of his rights." ${ }^{137}$ Egalitarian liberal theory's response to injustice is redistribution of the material, or materiallike, goods of society in a more equitable fashion, through the creation and protection of the rights of the individual.

\section{B. Justice as Distribution of the Symbolic}

Another school of thought argues that injustice can be cultural and symbolic and can arise from domination, non-recognition, and disrespect. ${ }^{138}$ The cultural group or community appears as a key site in which justice and injustice are meted out. The individual cannot be understood abstracted from his cultural setting, because culture is vital to making autonomous individual choices. ${ }^{139}$ Identity is thus not pre-constituted but shaped by cultural interaction and relationships. The remedy for such injustice is to develop and protect the rights of cultural groups. For the communitarian, interested in cultural distributory justice, the remedy is to enhance recognition.

\footnotetext{
132 Iris Marion Young, Justice and the Politics of Difference (Princeton: Princeton University Press, 1990) at 16.

133 Ibid.

134 Ibid at 25.

135 Costas Douzinas \& Adam Gearey, Critical Jurisprudence: the Political Philosophy of Justice (Oxford: Hart Publishing, 2005) at 183.

136 Martha Nussbaum has contributed a considerably more complex theory of egalitarian liberalism that addresses many of the feminist critiques of the traditional model I present here. See Martha Nussbaum, Sex and Social Justice (New York: Oxford University Press, 1999) and Martha Nussbaum, Women and Human Development: the Capabilities Approach (Cambridge: Cambridge University Press, 2000).

137 Douzinas \& Gearey, supra note 135 at 181.

138 Charles Taylor, Multiculturalism and "The Politics of Recognition" (Princeton: Princeton University Press, 1992) at 25.

139 Will Kymlicka, Liberalism, Community and Culture (Oxford: Oxford University Press, 1989) at 165 .
} 


\section{Justice as Process}

In theories which define justice as a process, attention is placed on the institutional context and the structures, practices, rules, and norms that guide decisions and the language and symbols that drive them. ${ }^{140}$ From this paradigm, justice cannot be achieved by distributing things or symbols, but rather by encouraging a democratic process which is participatory and empowering. In this model, a vision of the self emerges that is neither pre-constituted nor culturally determined. The self is dynamic, responsive, and contingent. For Young, "the self is a product of social processes, not their origin" "141 and "identity is constituted relationally, through involvement with - and incorporation of - significant others and integration into communities." ${ }^{142}$ The individual does not precede the group, because "people's identities are partly constructed by their group affinities." Groups are not things in the classical liberal sense - "they are real not as substances, but as forms of social relations." ${ }^{144}$ The individual and group need to be theorized together, because individuals identify with a group as a result of their similar experiences or ways of life. Thus, groups and individuals are not inherently or essentially bound together - they come together through social relations.

Others who have rejected the pre-constituted or culturally-determined conceptions of identity have gone even further. Identity and the individual exist at the moments of interaction with others: "Identity...is an ongoing dialogue with others which keeps changing my image for others and re-drawing my selfimage. ${ }^{145}$ The idea that gender identity is performed ${ }^{146}$ and that the production of ethnicity is a tournament with individual performance measured in relation to larger frames ${ }^{147}$ supports this dynamic, deconstructed vision of the self in relation to others. Defining justice as a process leads to conceptions of rights not as things or tools, but as "communally recognized rituals for securing attention in a continuing struggle over boundaries between people." ${ }^{148}$

An attention to process makes it possible to see liberal rights and communitarian relationships as co-existing. There is no need for an either/or choice between redistribution and recognition. ${ }^{149}$ The redistribution view rests on the abstract, universal individual as the unit underpinning redistribution; the cultural recognition view celebrates the differences among individuals which must be better affirmed. Yet, people experience injustice in both cultural and material (economic) terms, so claims for redistribution and recognition co-exist, rather than being mutually exclusive. The opposition between justice as socio-economic or

140 Young, supra note 132 at 22.

141 Ibid at 45.

142 Ibid.

143 Ibid at 9.

144 Ibid at 44.

145 Douzinas \& Gearey, supra note 135 at 181.

146 Judith Butler, Gender Trouble: Feminism and the Subversion of Identity (New York: Routledge, 1999).

147 Vigdis Broch-Due, "Violence and Belonging: Analytical Reflections" in Vigdis Broch-Due, ed, Violence and Belonging: The Quest for Identity in Post-colonial Africa (London: Routledge, 2005) 11.

148 Martha Minow, Making All the Difference (Ithaca: Cornell University Press, 1990) at 383.

149 Fraser, supra note 130 at 4. 
cultural rests on a false opposition, because both understandings of justice rest on the "right to have rights." holder of legal personality. Legal personality brings both formal recognition of the material (e.g. property rights) and abstract recognition of the symbolic (e.g. honour and respect). ${ }^{151}$ When groups clamour to be recognized as rights-bearers, they assert similarity between their group and those who currently enjoy rights. ${ }^{152}$

Fraser shows that neither theory of justice - as fundamentally about socioeconomic or cultural injustice - emphasizes transformation. ${ }^{153}$ There is no effort to "restructure the underlying generative framework." ${ }^{154}$ The politics of identity has focused on affirmation, which "corrects the inequitable social outcomes without disturbing the underlying framework that generates them." ${ }^{155}$ Policies aimed at addressing socio-economic injustice frequently seek to correct the inequity produced by existing political and economic structures without changing the underlying causes. It is possible to define justice and the remedies to injustice in such a way that both the redistribution and recognition challenges are included. ${ }^{156}$ By focusing on transformation, the processes that produce injustice, rather than their effects, can be analyzed and tackled. ${ }^{157}$ Young argues that the remedy to injustice can be found in processes that "support the development and exercise of people's capacities and their ability to express themselves and be heard." ${ }^{158}$

The next section applies these different theoretical approaches to justice to a theoretical framework on reparations.

\section{THREE THEORETICAL MODELS OF REPARATIONS}

The following section suggests three models of reparations: reparations as rights, as symbols, or as processes. These differing conceptions in turn connote differences in the nature and goals of reparations as an element in the post-conflict response to victims and survivors. They can be mapped on to the three theoretical models of justice outlined in the preceding section.

\section{A. Reparations as Rights}

The assertion that a breach of a victim's rights generates a right to compensation is the paradigmatic example of reparations as a right. ${ }^{159}$ This formulation is the organizing principle in international law's understanding of reparation and is based in a juridical understanding of the appropriate actions in the wake of breaches of law. Compensation may be aimed at actually repairing the

150

151

152

153

154

155

156

157

158

159

Hannah Arendt, The Origins of Totalitarianism (New York: Harcourt Brace, 1973) at 296.

Douzinas \& Gearey, supra note 135 at 184-186.

Ibid at 191.

Fraser, supra note 130 at 23.

Ibid.

Ibid.

Ibid at 31 .

Ibid at 33.

Young, supra note 132 at 38.

Pablo de Greiff, "The Role of Reparations in Transitions to Democracy" (Paper delivered at the Justice and the World Economy: Achieving Global Justice Seminar Series, May 2004) [unpublished]. 
harm, or making an effort in that direction. Reparation can be achieved through restitution of things (like property) or rights (citizenship rights or rights to legal personality). The rights-based architecture of reparations explains why the restoration of individual property rights was the only form of reparations permissible under the ICTY and ICTR statutes.

Rights-based conceptions of reparation can be understood as part of the liberal paradigm of "Justice as Distribution", with the injustice being repaired understood in material and socio-economic terms. Rights-based understandings of reparations dominate when justice is understood in material distributive terms. The effect is that this kind of reparations emphasizes better distribution through compensation, with the abstract, liberal individual as the core unit of reparations.

Reparations sometimes include giving recognized victims preferential access to services and public goods. Turning health care or schooling into a good which can be preferentially allocated is another example of reparations framed as rights. The right to reparations operates to transform a service into a material, thing-like entitlement. Pushing victims to "the head of the line" might help to address the substantive problems that victims continue to endure as a result of the violations committed against them - for example, their increased need for health care or public transportation due to disabilities. Preferential access, in the form of subsidies for secondary school fees and medical cards for access to hospitals, is one element of the Rwandan government's current approach to reparations. ${ }^{160}$

The reality is that it is not possible to provide full reparations to any victim of massive human rights crimes because "no market measures exist for the value of living an ordinary life, without nightmares." ${ }^{161}$ As it is impossible to repair the harms caused by massive human rights violations, perhaps reparations understood through the framework of "Justice as Distribution of the Material" is only part of the picture.

\section{B. Reparations as Symbol}

Reparations could instead be thought of as a symbolic act. Symbolic forms of reparations include burials of the dead or disappeared, commemorations, and the re-naming of public monuments after victims. Here, social, moral, psychological, and religious meanings are at the heart of reparations, as opposed to transfers of material things which could never achieve anything close to a return to the preconflict situation. ${ }^{162}$ Emphasizing the symbolic nature of reparations does not imply rejecting monetary compensation. Rather, in view of the inherent limits of compensation, any material transfers become symbolic objects around which wrongs are acknowledged. ${ }^{163}$ In this understanding, programs that give survivors preferential access to services may be a way of honouring the debt that society owes them. $^{164}$

Understandings of reparations which stress their symbolic rather than rightsbased nature lead to aims related to constructing meaning in the public sphere.

\footnotetext{
160 Rombouts, 2004, supra note 51.

161 Minow, 1998, supra note 80 at 104.

162 Ibid at 104-107.

163 Christopher Kutz "Justice in Reparations: The Cost of Memory and the Value of Talk" (2004) 32:3 Philosophy \& Public Affairs 277 at 279.

164 Roht-Arriaza, supra note 52 at 198-99.
} 
Reparations work individually to restore the honour of victims. ${ }^{165}$ For victims of sexual violence and torture, the restoration of dignity may be the most essential element of rehabilitation, both individually and as members of society. ${ }^{166}$ They also function collectively, beyond repairing individual victims or groups of victims, as they signal that a line has been drawn between past and present. ${ }^{167}$ Reparations as symbol look for an acknowledgement of responsibility and apology by the wrongdoer, frequently the state. Acknowledgement and apology have a symbolic reparatory effect for the individual and society because they help to reflect and reconstitute a moral community. ${ }^{168}$

Understanding reparations as a symbol thus speaks to a more communitarian approach to justice, which regards injustice as caused by mistakes of recognition. The unit to be repaired is not only the individual, but the individual as part of her society. In this understanding, both individuals and collectivities have rights to reparation.

\section{Reparations as Process}

In characterizing reparations as a process, emphasis is placed on the role of reparations in the complex transition out of a period of human rights violations, for individuals and for society. Reparations programs can be defined as administrative processes, established by statutes which define their mandate, jurisdiction, modes of working, and accountability and decision-making structures. ${ }^{169}$ As a process, reparations are backward-looking, as they aim to repair the violations of victims' rights, and forward-looking as they seek to advance the purposes of peace and reconciliation and embed the protection of such rights in the future. ${ }^{170}$ In a processoriented definition of reparations, a number of broader aims, such as reconciliation and development, may be possible goals.

Process-centered understandings can emphasize the role of reparations in forging a path towards reconciliation. Reparatory measures, like cash compensation to victims and public acts of commemoration, facilitate reconciliation by recognizing the victim's humanity and signaling the society's intention to transform itself. For example, the belief in the South African Truth and Reconciliation Commission's potential for reconciliation lay in the idea that the process itself of truth-telling and acknowledgement would build the foundations for a new nation. ${ }^{171}$

165 Nancy L. Rosenblum, "Justice and the Experience of Injustice" in Martha Minow, ed, Breaking the Cycles of Hatred: Memory, Law, and Repair (Princeton: Princeton University Press, 2002) 75 at $98-99$.

Judith L. Herman, "Peace on Earth Begins at Home: Reflections from the Women's Liberation Movement" in Minow, supra note 165 at 195.

167 Ruti Teitel, Transitional Justice (Oxford: Oxford University Press, 2000) at 127.

168 Minow, 1998, supra note 80 at 114.

169

Jaime E. Malamud-Goti \& Lucas Sebastín Grosman, "Reparations and Civil Litigation: Compensation for Human Rights Violations in Transitional Democracies" in De Greiff, 2006, supra note 32 at 540.

170

Teitel, supra note 167 at 127.

171 Brandon Hamber \& Richard Wilson, "Symbolic Closure through Memory, Reparation, and Revenge in Post-conflict societies" (Paper delivered at the Traumatic Stress in South Africa Conference, January 1999) [unpublished]. 
Process-based understandings of reparations can lead to assertions that reparations should be understood as tools to promote social and economic development. The aims of reparations become integrated into the process of social transformation following a period of conflict. Victims' rights to reparations and their claims are recognized to the extent they are compatible with the government's plans for social, political, and economic development. ${ }^{172}$

These process-based understandings of reparations contrast to the other models based on Justice as Distribution. Rights-based and symbolic understandings of reparations see the realization of rights and symbols as tangible outcomes which emerge at a definable post-conflict moment. They see the "reparatory transaction" - with a clear start and endpoint - as the culmination of a successful reparations program. In understanding reparations as a process, the rights and symbols of reparations are folded into a broader idea of reparations that is defined by the process, rather than the individual component parts. Process-based understandings of reparations incorporate rights, symbols, and social measures like rehabilitation and development. But rather than "being reparations", these are seen as the building blocks of a process of transition which is specific to each post-conflict context, dynamic, contingent, open-ended, and participatory.

The following chart summarizes these three understandings of reparations in the context of different theories of justice.

\begin{tabular}{|l|c|c|c|}
\hline \multicolumn{1}{|c|}{ Definition of Justice } & \multicolumn{2}{|c|}{ Justice as Distribution } & Justice as Process \\
\hline Core to Justice & $\begin{array}{c}\text { Material / Socio- } \\
\text { economic }\end{array}$ & Culture & $\begin{array}{c}\text { Processes, structures, } \\
\text { institutions }\end{array}$ \\
\hline$\underline{\text { Identity, Self, }}$ Community & $\begin{array}{c}\text { Pre-existing, abstract, } \\
\text { universal individual }\end{array}$ & $\begin{array}{c}\text { Culturally-determined, } \\
\text { groups need rights }\end{array}$ & $\begin{array}{c}\text { Dynamic, responsive, } \\
\text { contingent, relational }\end{array}$ \\
\hline$\underline{\text { Law's Role }}$ & Rights for individuals & Rights for groups & $\begin{array}{c}\text { Discursive site, plural } \\
\text { normativity }\end{array}$ \\
\hline$\underline{\text { Remedy }}$ & $\begin{array}{c}\text { Better redistribution } \\
\text { Reparations are ... }\end{array}$ & Better recognition & $\begin{array}{c}\text { Better democratic } \\
\text { process, participation, } \\
\text { empowerment }\end{array}$ \\
\hline$\underline{\text { Repair through ... }}$ & $\begin{array}{c}\text { Respect for legal } \\
\text { rights to property and } \\
\text { personality (e.g. } \\
\text { compensation, equal } \\
\text { citizenship) }\end{array}$ & $\begin{array}{c}\text { Restoring honour and } \\
\text { bearing witness }\end{array}$ & $\begin{array}{c}\text { Symbols } \\
\text { Processes } \\
\text { processes that see } \\
\text { transition as both } \\
\text { forward \& backward- } \\
\text { looking }\end{array}$ \\
\hline
\end{tabular}

\section{TOWARDS FEMINIST THEORIES OF REPARATIONS}

It is important to analyze what problems of injustice reparations are hoping to solve because the answers to these questions affect design decisions taken in establishing reparations programs. Furthermore, because there is relatively little

172 Teitel, supra note 167 at 147. 
theorizing about the reasons that reparations program are pursued, implied assumptions and norms may affect decision-making. The power of international institutions and processes may mean that their normative frames are preferred over activist discourses: "The structural underpinnings of conflict may be intentionally or inadvertently omitted from the transitional justice account through the adoption of the dominant scripts." ${ }^{173}$ As transitional justice has tended to be framed in ways which reflect male experiences of war, interrogating the hidden normative frameworks in understandings of reparations is important to developing a feminist approach. In the following section, I explore feminist concerns with understanding reparations as rights or symbols. I conclude by arguing that a feminist theory of reparations should understand reparations as a process.

\section{A. Reparations as Rights: The Dominant Paradigm}

The Reparations as Rights model dominates most contemporary practice and discourse on reparations. In international law, reparations has been clearly defined in rights-based terms. Originally an inter-state remedy, the right to reparation is now protected for individual victims through human rights law and international criminal law. Reparations are individual rights, and there is reluctance to wade into the terrain of collective rights, as shown by the curtailment and eventual abandonment of the ICTR's programs to provide housing and access to medicines to some victims, survivors, and witnesses of the genocide in Rwanda. The new procedures established in the International Criminal Court for reparations may be the first sign of a retreat from a narrow, rights-based conception of reparations.

Among activists and commentators, the predominance of the "Reparations as Right" model can also be seen. In a book based on case studies and thematic analyses, De Greiff of the International Center for Transitional Justice posits that reparations have three inter-linked goals: Recognition, Civic Trust, and Solidarity. ${ }^{174}$ The hallmark of a constitutional democracy is the ability to recognize one another not only as individuals but as rights-bearing citizens, ${ }^{175}$ and reparations foster the recognition of citizenship based on equal rights. By Civic Trust, De Greiff refers to the trust among members of the same political community that both engenders and reinforces expectations about norms and codes of conduct. As this trust is eroded during periods of conflict, reparations must pursue the goal of rebuilding trust in others and trust in public institutions. Reparations must also pursue Solidarity, or the empathy to imagine being in the place of others. As policy choices which demonstrate the concern of the traditionally more advantaged for the interests and welfare of the disadvantaged, reparations programs can help to form a new social contract in which the dignity and interests of the marginalized are more fully recognized. ${ }^{176}$

Although using terms like "Recognition" and "Solidarity" to describe the goal of reparations, de Greiff departs from an understanding of reparations as rights.

173 Lorna McGregor, "International Law as a 'Tiered Process': Transitional Justice at the Local, National and International Level" in Kieran McEvoy \& Lorna McGregor, eds, Transitional Justice from Below: Grassroots Activism and the Struggle for Change (Oxford: Hart Publishing, 2008) at 59.

174 De Greiff, 2006, supra note 32 at 459.

175 Ibid at 460 .

176 Ibid at 464. 
The claim for Recognition as an equal citizen is not intended to be a cultural or symbolic process to acknowledge the specific needs of marginalized social groups. Instead, such a call for recognition is consistent with the classical liberal emphasis on the individual as a rights-bearer and justice as formal respect of individual rights by the state and society. The goal of Solidarity is an argument for greater equality and respect among citizens, with reparations as a tool to demonstrate this equality, in part through a distribution of tangible (like monetary compensation) and intangible (like full citizenship) goods from the advantaged to the disadvantaged. The concern for rebuilding civic trust is premised on a notion of citizens interacting in the public sphere as neutral and inter-changeable individuals, rather than as socially-situated members of a range of social, cultural, and political communities.

\section{B. Problems with Reparations as a Right}

There are problems with defining reparations solely as a right. First, the "Reparations as a Right" model implies that justice is to be achieved through redistribution of the material (including property and legal rights). In the idea that reparations are the recognition of individual rights over communitarian interests, ${ }^{177}$ a right is used to select those most eligible for reparation from among all those harmed. Thus, the right shifts the focus from harm to (all) victims to a recognition of (a few) individuals' rights to bodily and property rights. With the instrument of rights, the liberal conception frames and then sidesteps distributive justice questions.

Framed as rights, then, the quest for reparations should not be mistaken as a project to transform the distribution of wealth and power in a post-conflict society. Indeed, Torpey argues that reparations is part of the "“juridification' of politics." In this regard, de Greiff is correct to caution against a narrow, legal approach to reparations decisions, calling instead for a fundamentally political approach. ${ }^{179}$

While rights-based conceptions of reparations do consider public and societal acknowledgement and respect for victims, the resulting remedies, such as compensation or restitution, repair the individual's private sphere interests - their patrimony. Led by this normative framework, the policy decision to focus on material restitution serves to exclude women and other marginalized groups from reparations, as very often they lacked assets before the conflict. It can continue to disadvantage them if post-conflict laws maintain that women do not have rights to own land.

The focus on individual harm is a weakness of individual reparations measures because it prevents a comprehensive picture of the nature and extent of the period of human rights violations. ${ }^{181}$ Incorporating the restoration or recognition of legal personality helps to correct the narrow focus on patrimonial interests, but it does not necessarily help to broaden the reparatory transaction beyond the individual

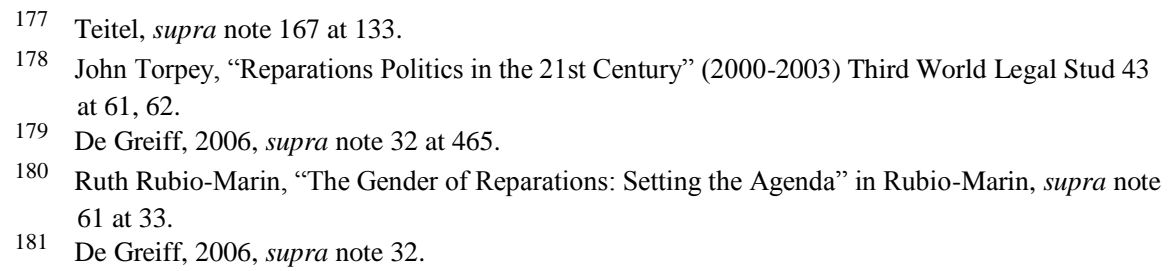


victim/citizen and state. This narrowing has an exclusionary effect when considering the aftermath of conflict from a gendered perspective. Women tend to be victims of conflict-related violations which are dispersed through a community, such as forced displacement, economic insecurity, starvation, and increased caregiving responsibilities due to breakdown of social services.

The existing architecture of reparations is thus built on a liberal framework of individual rights and an understanding of justice based on material distribution. This maps onto an understanding of conflict as intra-male public violence that does not reflect women's experiences. ${ }^{182}$ A gendered understanding of reparations must push beyond an understanding of harm built on civil and political rights violations to incorporate economic conditions, structural violence, and pre-existing inequality and discrimination. ${ }^{183}$ Efforts to engender reparations processes challenge this architecture by expanding the definition of harms. Sexual violence is an endemic feature of conflict, but an exclusive focus on rape in wartime risks sexualizing women. ${ }^{184}$ According to a South African critic, "gender justice can only be furthered if there is a focus not just on the crime [of rape] but its context, motivation, and location within a continuum of violence." ${ }^{185}$ Expanding the definition of harm beyond the male-centred, political violence norm would need to include elements like forced domestic labor, women's increased caretaking responsibilities, and forced displacement. Reparations would need to address economic, social, and cultural harms in order to fully address women's experiences of conflict. ${ }^{186}$

Reparations programs that include preferential access to education, housing, and health care can help to address the narrow focus on compensation and harm to civil and political rights, as these programs help to repair non-patrimonial interests. Nevertheless, they remain within a rights-based understanding of reparations. Individuals must be identified as eligible for the programs, often through a special card or status. For them to feel that this preferential access constitutes reparations, access must be regarded as an entitlement based on their status as victim. Access to a service thus acquires the characteristic of a right associated to their personhood.

There are some pitfalls to delivering reparations through preferential access to services. The program might fail to establish a connection between the redistributive program and the acknowledgement of responsibility by the state or perpetrator. Preferential access to services is not of much use if the victim has no need of the services. When there is little overall service provision or when many victims have a right to such measures, being granted preferential access may mean

182 Fionnuala Ní Aoláin \& Eilish Rooney, "Underenforcement and Intersectionality: Gendered Aspects of Transition for Women" (2007) 1 International Journal of Transitional Justice 338 at 343 .

183 Ruth Rubio-Marín and Pablo de Greiff, "Women and Reparations" (2007) 1 International Journal of Transitional Justice 318 at 326.

184 Ibid.

185 Valji, supra note 21 at 11.

186 Daniel Aguirre \& Irene Pietropaoli, "Gender Equality, Development and Transitional Justice: The Case of Nepal" (2008) 2 International Journal of Transitional Justice 356 at 358; Makau W. Mutua, "Transitional Justice in Sexual and Gender-Based Violence" (July 17, 2008). Buffalo Legal Studies Research Paper No. 2008-18 online: SSRN <http://papers.ssrn.com/sol3/papers.cfm?abstract_id $=1162240>$ at 2 . 
little in practice. Affirmative action may provoke resentment among others who feel they have just as much right to the public good being "granted" by the government in this preferential manner.

The individual at the centre of the reparatory effort in a rights-based understanding is thought of in abstract and neutral terms. Feminist and communitarian critics have shown that liberalism has an impoverished understanding of the individual, disembodied from the social context that forms her. Applying this analysis to understanding reparations suggests that positioning a gender-neutral citizen at the heart of reparations will obscure the social factors which produce identity and the structural inequalities which position individuals in communities. $^{187}$ Looking at preferential access forms of reparations reveals some of the resulting problems of the liberal notion of identity. If women are the primary beneficiaries of these forms of reparations, they may contribute to stereotypical views of women as "passive recipients of assistance measures rather than active citizens who require recognition and compensation for the fact that their rights have been violated." ${ }^{188}$ In societies where unequal or preferential access to state services were characteristics of colonial or oppressive rule, disparities in access to services, as a form of reparation, might sow the seeds of further conflict, instead of encouraging reconciliation. ${ }^{189}$ Furthermore, these programs might easily overlook that, given unequal starting points in society, women and men are unlikely to get the same benefits from the same program. ${ }^{190}$ The existing infrastructure upon which preferential access programs are based may contain preexisting gender biases.

This problem is part of the broader feminist critique of the Reparations as Rights model: it is impossible to talk of "repair" and "restitution" when the preconflict situation was marked by inequality based on gender, ethnicity, class, and other social markers. A feminist approach cannot be a search for social stability or a return to an old way of life. As Saito asks:

as we struggle for compensation, for reparations and for the reconstruction of societies, ... are [we] struggling in ways that support accommodation and reconciliation with wrong, or ... are [we] honouring resistance to wrong and participating in the dismantling of broader structures of oppression. ${ }^{19}$

Echoing the voices of women activists, feminist critics have concluded that reparations cannot produce justice by repairing to a pre-existing condition of injustice. $^{192}$ According to Louise Arbour, then High Commissioner for Human

187 Colleen Duggan, Claudia Paz y Paz Bailey \& Julie Guillerot "Reparations for Sexual and Reproductive Violence: Prospects for Achieving Gender Justice in Guatemala and Peru" (2008) 2 International Journal of Transitional Justice 192 at 197.

188 Aguirre \& Pietropaoli, supra note 186 at 333.

189 Roht-Arriaza, supra note 52 at 199-200.

190 Rubio-Marin \& de Greiff, supra note 183 at 333.

191 Natsu Taylor Saito, "The Symbolism and Substance of Redress and Reconstruction" (2000-2003) Third World Legal Stud 161 at 168.

192 Rubio-Marin \& de Greiff, supra note 183 at 331; Christine Chinkin "Gender, Human Rights, and Peace Agreements" (2003) 18 Ohio St J Disp Resol 867 at 876; Saris \& Lofts, supra note 129 at 81; Aguirre \& Pietropaoli, supra note 186 at 363. 
Rights, "Transitional justice must reach ... into the human rights violations that pre-existed the conflict and caused, or contributed to it." that preceded the conflict - like domestic violence, socio-economic inequality, and systemic discrimination - come into view as part of the reparations debate. ${ }^{194}$ High levels of "post-violence violence" throw into question the "peace" that supposedly underpins reparations decisions. ${ }^{195}$ Massive economic deprivation is most likely to affect women and children, but transitional justice norms do not define this as a threat to security and peace. A feminist approach to reparations must ask whether "an emphasis on ending or containing political violence per se constitutes a full and thorough response to the multitudes of harms that both accompany and survive past the ending of formal ... hostilities." ${ }^{196}$

Paying attention to the pre-existing conditions of those claiming reparations unravels the logic of reparations. It exposes that rights-based understandings of reparations are essentially aimed at correcting errors in the distribution of resources caused by the conflict. This correction, as Kutz explains, relies on a normativity, constructed independently, by the pre-conflict distribution of rights and entitlements. ${ }^{197}$ A "right to reparations" is intrinsically incapable of analyzing whether pre-conflict distributions were fair or just.

\section{Problems with Reparations as a Symbol}

The dominant account of reparations, as a right, thus presents a number of problems from a feminist standpoint. However, the solution does not lie in swinging to a "reparations as symbol" approach that protects groups through recognition and social standing.

Moving away from the individual's right to reparation to focusing on collective rights to symbolic forms of reparation may have negative effects for women and other marginalized groups. The communitarian notion of the embodied sociallysituated self leaves little room for agency and self-determination, important feminist concerns. ${ }^{198}$ Feminists have also critiqued the romantic view of community adopted by communitarians. The recognition of groups may in some cases be used as a justification for perpetuating inequality among and within groups. ${ }^{199}$

Advocating an approach to reparations based exclusively on symbolic forms of reparation may find little support among women's groups who articulate their concerns for reparations around day-to-day survival needs. Many victims' groups call for material forms of reparations and stress the need for recognition as rightsbearing individuals. Furthermore, it is not much of a feminist move to jettison the

193 Louise Arbour, "Economic and Social Justice for Societies in Transition (Second Annual Transitional Justice Lecture, New York University School of Law Center for Human Rights and Global Justice and the International Center for Transitional Justice, New York, 25 October 2006) [unpublished] at 2.

Duggan et al, supra note 187 at 207; Rubio-Marin, supra note 180 at 30.

195 Theidon, supra note 11 at 34.

196 Fionnuala Ní Aoláin"Political Violence and Gender during Times of Transition" (2006) 15 Colum J Gender \& L 829 at 847.

197 Kutz, supra note 163 at 302.

198 Lacey, supra note 5 at 54.

199 O'Rourke, supra note 31 at 272. 
hardness of rights for the softness of symbols, when in practice this would mean that the real work of reparations, as rights, would focus on an androcentric understanding of conflict. Given the importance of rights in the understanding of reparations advanced by women's rights activists, it does not make sense to argue that a feminist understanding of reparations must concentrate only on its symbolic dimensions.

Nevertheless, women articulate a need for measures to restore the dignity of survivors of the conflict, and very often these measures will take a symbolic form. Even the rights-based forms of reparation, like compensation or preferential access to services, function in a symbolic register: no amount of money or free health care will repair the victim, but the public choice to provide those forms of reparations sends a symbolic message about the desire to repair their dignity and standing in the community.

For feminists, however, dignity is a bit of Trojan horse. Sexual violence as a tool of war is decried by feminist activists because it physically and psychologically damages the woman or girl, and because it tarnishes her reputation in the community, sometimes leading to her permanent banishment. Reparation programs that aim to restore her dignity attempt to achieve a reconciliation between the victim and the family and community. But the stigma associated with surviving sexual violence is deeply enmeshed with attitudes that a woman's sexual chastity determines her worth and that a woman's body is an object which certain men, but not others, may legitimately access. ${ }^{200}$ In this context, restoring her dignity may reinforce patriarchal meanings attached to women's sexuality. ${ }^{201}$ Feminist ways to recognize the harm of sexual violence and restore dignity are far from obvious.

\section{Redefining Reparations as Processes}

Understanding reparations as rights or symbols presents some theoretical problems and fails to capture how women articulate their understanding of reparations. Instead of thinking of reparations as a program aiming to achieve material or symbolic justice goals, it makes more feminist sense to think of reparations as a process which is both forward and backward-looking and has an open outcome.

Victims of human rights crimes need both rights to property and symbolic respect in the social sphere: "a fundamental goal should be to ensure that any reparations model includes both material and symbolic components." theory has critiqued the ways in which rights both limit and structure claims for equality and recognition. ${ }^{203}$ By rejecting a dichotomy between rights and symbols,

\footnotetext{
200 Meintjes, supra note 10 at 12.

201 Rubio-Marin, supra note 180 at 33.

202 Ernesto Verdeja, "Reparations in Democratic Transitions" (2006) 12 Res Publica 115 at 122.

203 See Elizabeth M Schneider, "The Dialectic of Rights and Politics: Perspectives from the Women's Movement" in Katharine T Bartlett \& Rosanne Kennedy, eds, Feminist Legal Theory: Readings in Law and Gender (Boulder: Westview Press, 1991) 321; Judy Fudge, "The Canadian Charter of Rights: Recognition, Redistribution, and the Imperialism of the Courts" in Tom Campbell, KD Ewing \& Adam Tomkins, eds, Sceptical Essays on Human Rights (Oxford: Oxford University Press, 2001) 335; Frances Olsen, "Statutory rape: a feminist critique of rights analysis" (1984) 63 Tex L Rev 387; Stephanie Palmer, "Feminism and the Promise of Human Rights: Possibilities and Paradoxes" in Susan James \& Stephanie Palmer, eds, Visible Women: Essays on
} 
"Reparations as Process" has the possibility of answering both women's needs for material compensation and their needs for rehabilitation, recognition, and respect. For survivors of sexual violence or other highly stigmatized crimes, a strong connection exists between income generating opportunities and personal reputation, so the decision to pursue both types of reparations is crucial. Victims need to be respected as citizens, but in a way which recognizes that they are situated and contextually-influenced individuals.

A process-based approach to reparations, in corresponding to a process-based understanding of justice, also better responds to feminist concerns about a false opposition between socio-economic and cultural justice. ${ }^{204}$ The material or cultural definitions of justice and the remedies of redistribution or recognition lead to remedies which affirm rather than upset the root causes of inequality. If either the rights or symbol-based theories of reparations are taken in isolation, there is little room for exposing and questioning the assumptions that structure women's unequal citizenship and their roles as symbols of national purity. This focus on transformation explains why a feminist approach to reparations needs to address pre-existing laws that deny basic legal rights. It is impossible to realize the right to reparations, understood even in its narrowest terms as a right to monetary compensation, if laws denying rights to hold title to land or open bank accounts are not changed.

Feminist concerns about the construction of identity are better addressed through a process-based approach to reparations. The liberal, neutral individual of rights-based theories is, in practice, a description of the relatively privileged man, while the emphasis on culture and social groupings in communitarian theories often comes loaded with norms about women as symbols and protectors of the nation. ${ }^{205}$ To jettison this distinction, it is necessary to examine the reality of privilege and discrimination, across lines of race, gender, class, and other social markers, and construct reparations processes which question and disturb these structures.

Understanding reparations as a process helps to explain why local participation and decision-making are at the heart of reparations. ${ }^{206}$ The process of debating, designing, and implementing reparations becomes potentially reparatory in itself. In every conflict, there persists a "meta-conflict", or a conflict about what the conflict is about, and the reparations process can facilitate open and inclusive dialogue about these meanings. ${ }^{207}$ The justice in reparations is thus to be found not in the ideal allocation of rights and symbols, but in a process which the society perceives as having achieved a reparatory effect. This view helps to explain why women activists regard their active participation in politics as part of reparations. ${ }^{208}$ Their exclusion from political life is part of the structure of injustice before and

Feminist Legal Theory and Political Philosophy (Oxford: Hart Publishing, 2002) 91; Patricia J. Williams, The Alchemy of Race and Rights (Cambridge, MA: Harvard University Press, 1991).

204 This mirrors the argument in the development studies field that gender-sensitive approaches to development must address both women's practical and strategic gender needs; see CA Moser, Gender Planning and Development: Theory, Practice and Training (London: Routledge, 1993). Duggan et al, supra note 187 at 205.

207 O'Rourke, supra note 31 at 290.

208 Duggan \& Abusharaf, supra note 205 at 643. 
after the conflict. For reparations programs to achieve justice, they must, in the process of their design and implementation, remedy the gaps in representation in public life by specifically including women and other marginalized groups. The process of reparations must be participatory, inclusive, and democratic. Analyzing this process from a feminist perspective could usefully draw on the wide-ranging literature in feminist political science on political transitions. ${ }^{209}$

With a process-based justification of reparations, a range of goals can be pursued with a variety of policy instruments - legal claims, symbolic commemorative processes, public hearings, and monetary compensation, for example. A process-based definition ensures that a range of suitable remedies are available to a diverse pool of potential beneficiaries of reparations. For example, preferential access to services would allow cash-strapped governments to forego special funds to individually compensate victims, while at the same time providing a public recognition of victims' suffering. ${ }^{210}$ As some victims emphasize health and education needs over controversial compensation awards, such programs may directly meet victims" expectations. "Reparations as Process" provides an umbrella concept for the broad definition of reparations adopted by women's rights activists.

A more pragmatic view of a post-conflict transition process may also justify the "Reparations as Process" approach. ${ }^{211}$ A reparations program competes with other state priorities in the post-conflict period, such as investing in education, infrastructure, health care, and the judiciary. Governments may try to accommodate demands of victims' groups, the broader population, businesses, the international community, and other stakeholders. Permitting certain development measures to be understood as part of a reparations program allows the government room to respond to all these constituencies. This epitomizes reparations understood as a process, as it permits reparations to be both backward looking (in responding to victims) and forward looking (in responding to broader interests). To the extent that the conflict may have its roots in underlying inequalities and socioeconomic conditions that arose from chronic government under-investment in its citizens' welfare, such measures could help to set the country on a path towards both reconciliation and a more stable future.

Should reparations, as a process, be thought of as part of development? This is hotly contested. $^{212}$ The central objection is that the reparations-as-development formulation permits the government to fulfill its obligations by funding developmental activities which it is already bound to undertake, thus denying victims justice. $^{213}$ Related to this criticism is the concern that the concept of development as reparations lacks the link between the individual victims and the reparations measure. ${ }^{214}$ A third objection concerns the practical impossibility of achieving social development through a short-term reparations program, no matter

\footnotetext{
209 O'Rourke, supra note 31 at 285.

210 Roht-Arriaza, supra note 52 at 198-99.

211 Ibid at 189.

212 For an overview of the debate, see Pablo de Greiff \& Roger Duthie, eds, Transitional Justice and Development: Making Connections (New York: Social Science Research Council, 2009).

213 Roht-Arriaza, supra note 52 at 189.

214 De Greiff, supra note 159 at 7.
} 
how large or well-funded. Some feminist commentators argue that there should be a bright line between reparations and development. ${ }^{215}$

Others, however, argue that the rigid distinction between reparations and development should be abandoned. ${ }^{216}$ Activities which might be classified as development could be framed in ways which give them reparatory effects and meanings. There seems to be some support for this more expansive approach to reparations in the views of women activists. Under the concept of reparations, women include claims that might look like development: education, housing, economic policies to improve access to markets, and reforms to discriminatory laws and practices.

But many activists are emphatic that the government cannot "undertake development instead of reparations. ${ }^{217}$ One way of understanding this concern is that it is about lack of political will: victims are concerned that their needs will be overlooked in the name of general social policy goals. The relationship between reparations and development raises some tough questions. How does one reconcile the rejection of development as a goal of reparations with a feminist approach to reparations that reveals and repudiates pre-conflict structural inequalities and injustices? When approached from a feminist perspective, the relationship between reparations and development is arguably where the rubber hits the road.

Notwithstanding these disagreements, it can be argued that development would bring to the reparations agenda norms and ways of working. ${ }^{218}$ There is a huge variety of approaches to development policy and practice, ranging from the World Bank to local level NGOs. A strand of development theory and practice values local knowledge, agency, participation, bottom-up planning, and empowerment. Practical working methods have been developed to achieve these goals. ${ }^{219}$ Policy and practice on reparations could learn from this experience.

From the vantage point of feminist theory and women activists, "Reparations as Process" offers the best theoretical model for understanding reparations. There is no blueprint for approaching reparations as a process, as it requires negotiation in the specific post-conflict context in which reparations decisions are being made. There are some characteristics of such an approach that can be discerned. It is easiest to begin by describing what reparations are not: they are not only rights, or symbols, and they cannot be achieved simply with technical or juridical methods. "Reparations as a Process" results in an approach which incorporates rights-based, symbolic, and redistributive goals. As ICTJ's study noted, the most just

\footnotetext{
Goldblatt, supra note 63 at 211.

16 Saris \& Lofts, supra note 129 at 91; Aguirre \& Pietropaoli, supra note 186 at 366.

217 Nairobi Declaration, supra note 61 at 3-B.

218 Aguirre \& Pietropaoli, supra note 186 at 369.

219 See Arturo Escobar, Encountering Development: the Making and Unmaking of the Third World (Princeton, N.J.: Princeton University Press, 1995); Uma Kothari \& Martin Minogue, eds, Development Theory and Practice: Critical Perspectives (Houndmills, UK: Palgrave, 2002); Majid Rahnema \& Victoria Bawtree, eds, The Post-development Reader (London: Zed Books, 1997); Andrea Cornwall, The Participation Reader (London: Zed Books, 2011); Kriemild Saunders, ed, Feminist Post-development Thought: Rethinking Modernity, Post-colonialism \& Representation (London: Zed Books, 2002); Robert Chambers, Ideas for Development (London: Earthscan, 2005).
} 
approaches to reparations are complex and multi-faceted. ${ }^{220}$ Reparations are hybrid and both forward and backward-looking. They demand an inter-disciplinary approach, as they trample through the delineations between law, politics, economics, development, and public policy. A feminist theoretical approach to reparations requires an acknowledgement of the importance of rights and symbols, framed by a broader concern for the contexts in which reparations decisions are made and the public processes that produce them. It must see the individual as both a rights-bearing citizen and a member of a community. At the centre of reparations should be an understanding of the self as responsive, contingent, and constructed relationally. This understanding of identity would provide the theoretical room for the dynamic and sometimes conflicting identities performed by women in the aftermath of conflict (for example, a reparations claim from a woman who joined a fighting force and was then forced into sexual slavery, as both a victim and perpetrator). This process-based understanding opens space for a definition of justice, and a justification for reparations, that is open-ended, inclusive, and able to be adapted to the societal context. Most fundamentally, a feminist approach to reparations questions what we are trying to "repair" and pushes for an understanding of "post-conflict" as an opportunity for transformation.

\section{CONCLUSION}

The notion of reparations encompasses debates about the relationship between individual and society, the nature of political community, the meaning of justice, and the impact of rights in social change. The prevailing transitional justice winds reflect "a highly limited politics intended, for the most part, less at democracybuilding, than at the threshold aims of peace and stability" attempt to create a new world order of liberal democracies in which politics is forever deferred and history comes to an end." ${ }^{222}$ The dominance of rights-based approaches to reparations reflects consistency with these trends. But, as I have shown, this predominant normative framework is out of step with the understanding of reparations circulating among many women activists. The theoretical approach to justice and reparations developed in this paper helps to explain the gap between the international normative framework and activist discourses. Based on distributive, communitarian, and critical theories of justice, I argued that reparations can be thought of as rights, symbols, or processes. Approaching reparations as either rights or symbols is rife with problems when approached from an activist and feminist theoretical standpoint. As decisions about reparations programs are and should be determined by the political, social, economic, and cultural context, a blueprint for "a feminist reparations program" is impractical and ill-advised. However, the strongest feminist approach to reparations would depart from an understanding of reparations as a process. Reparations are fundamentally political, meaning that there will be compromise

220 Rubio-Marin \& de Greiff, supra note 183 at 321; Pablo de Greiff, "Repairing the Past:

Compensation for Victims of Human Rights Violations" in De Greiff, 2006, supra note 321 at 913.

221 Ruti Teitel, "Transitional Justice in a New Era” (2003) 25 Fordham Int'l LJ 893 at 898

222 Anne Orford "Commissioning the Truth" (2006) 15 Colum J Gender \& L 851 at 852. 
and that there might be mistakes. Neither the hard language of rights nor the resonance of symbol will provide answers to the long-view, structural transformations that the post-conflict moment demands. 